University of Louisville

ThinkIR: The University of Louisville's Institutional Repository

Electronic Theses and Dissertations

1942

\title{
The Athenian constitution from Solon to Pericles B.C. 594-B.C.
}

\section{7.}

Norman Reynolds

University of Louisville

Follow this and additional works at: https://ir.library.louisville.edu/etd

Part of the European History Commons

\section{Recommended Citation}

Reynolds, Norman, "The Athenian constitution from Solon to Pericles B.C. 594-B.C. 457." (1942).

Electronic Theses and Dissertations. Paper 1864.

https://doi.org/10.18297/etd/1864

This Master's Thesis is brought to you for free and open access by ThinkIR: The University of Louisville's Institutional Repository. It has been accepted for inclusion in Electronic Theses and Dissertations by an authorized administrator of ThinkIR: The University of Louisville's Institutional Repository. This title appears here courtesy of the author, who has retained all other copyrights. For more information, please contact thinkir@louisville.edu. 
UNIVERSITY OF LOUISVILIE

THE ATHENIAN CONSTITUTION FROM SOLON TO PERICLES

B. C. $594--$ B. C. 457

\author{
A Dissertation \\ Submitted to the Foulty \\ Of the Graduate School of the University of Louisville \\ In Partial Fulfillment of the \\ Requirements for the Degree \\ Of Master of Arts
}

Department of History

By

NORMAN REYNOLDS

Year

1942 
NAME OF STUDENT:

TITLE OF THESIS:

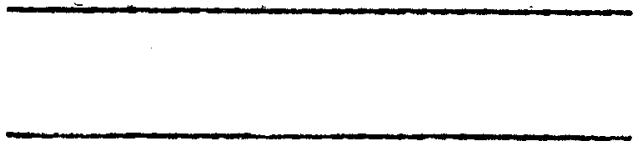

APPROVED BY READING COMMTTEE COMPOSED OF THE FOLLOWING MEMBERS :

NAME OF DIRECTOR:

DATE: $5-16-42$ 
5

$\frac{1}{2}$

$\dot{\infty}$

ז

THE ATHENIAN CONSTITUTION FROM SOLON TO PERICLES

60214 
T A B L E OF CON TEN T S

\author{
INTRODUCTION -- PAGE 1 \\ Questions -- Solon -- Cleisthenes -- The Changing Constitution -- \\ Method of Treatment -- The Thesis \\ I THE PRE-SOLONIAN CONSTITUTION -- PAGE 5
}

a. Legendary Period -- Formation of the Constitution -- Page 5 Character of Early Athenian History -- Primitive Organization of Attica -- Lack of Unity -- Theseus Proposed Union -- Athens the New Political Center -- Kingship Opened to Other Families -- Rise of the Nobles -- Limiting of the Monarchy -- Creation of the Polemarch -- The Office of Archon -- Introduction of Wealth as a Factor in Politios -- Terms of Office Reduced to One Year -- Institution of the Junior Archons -- The Areopagus -- Its Administrative Powers -- Civic Strife -- Cylon's Effort at Tyranny -- The Crime of Megacles -- Curse of the Alcmaeonids -- Oppression of the Common People

b. The Reforms of Draco -- Page 15

Nature of the Reforms -- The Archons and the Areopagus -- The Ecclesia -- The Council of Four Hundred -- The Code of Law

c. The Constitution of Draco -- Page 19

Nature of the Constitution -- The Class System -- The Archonship -- The Areopagus -- The Ecclesia -- The Generals -Summary

II THE SOLONIAN CONSTITUTION - - PAGE 22

a. Failure of the Draconian Reforms -- Page 22

The Problem of Debt Slavery - Factions of the Plain, Hill and Shore -- Source of Solon's Fome -- He Persuades the Alcmaenids to Submit to Jury Decision -- Solon's Antecedents -- Chosen Archon

b. The Solonian Reforms -- Page 26

The Debt Cancellation -- Public Reactions to the Measure -Abolition of Draco's Code -- Class System Based on Wealth -Offices Thrown Open to the Lot 


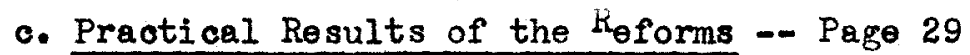

Democratic Features -- Overwhelming Influence of the Aristocracy

d. The Constitution of Solon -- Page 30

Constitutions of $\mathrm{D}_{\mathrm{raco}}$ and Solon Compared -- The Tribal System

-- The Class Divisions -- Possibilities for Factional Strifo --

Naturalization of Citizens -- A Device to Prevent Tyranny --

The Archons -- The Areopagus -- Its Membership -- The Ecclesia

-- The Counoil of Four Hundred -- The Heliaea -- It Umpires All

Disputes -- Remaining Features of the Constitution -- Solon

Lays Down His Power

e. Development of the Arohonship -- Page 40

Rivalry for the Archonship - The Office Aimed at Abolition of Monarchy -- Term of Office Reduced to One Year -- Function of the Junior Archons -- Great Power of the Archon Eponymus

f. Public Reaction against Solon's Constitution -- Page 43 Reasons for Solon's Ten Year Departure from Athens -- Return of the Exiles -- Alameonid Leadership of the Shore.-- Struggle between Shore and Plain -- Peisistratus Champions the Hill -One-Year Suspension of the Archonship -- Solon's Return to Athens -- Damasias's Attempt at Tyranny -- Increased Influence of Peisistratus -- His Powerful Position -- Solon Warns Athens against Him -- Peisistratus Gains the Tyranny -- Solon Opposes Him -- Peisistratus Wins Solon's Support -- Death of Solon -Peisistratus Forced from the Tyranny by Megacles and Lyourgus -- Digression on the Rise of Hiltiades in the Chersonesus -Quarrel between the Plain and the Shore -- Megacles Arranges Peisistratus's Return to the Tyranny -- His Second Exile -Peisistratus's Ten-Year Preparation for Return to Power -Conquest of Athens by Peisistratus -- Nature of the Tyranny -Encouragement of Agriculture -- Arts and Religious Festivals Encouraged -- Foreign Policy of Peisistratus -- Digression on the Family of Miltiades -- Death of Peisistratus -- Hippias Appoints Young Miltiades to Administer Affairs in Chersonesus -- Miltiades Creates for Himself a Tyranny in Chersonesus

g. The Constitution under Peisistratus -- Page 58 The Life-Archonship - The Tyranny only Concerned with Administrative Matters -- Legislative and Judicial Powers Untouched -- Mildness of the Tyranny

h. Solon's Constitution under Peisistratid Management -- Page 60 The Archons -- Their Duties -- The Areopagus -- Its Importance -- Guardian of the Laws -- Judicial Functions -- The Council of Four Hundred -- Its Powers -- The Ecolesia -- The Heliaea -- The Generals -- Laws of Citizenship -- Much of the Constitution Inoperative under the Tyranny 
III THE CONSTITUTION OF CLEISTHENES -- PAGE 66

a. The Fall of Hippias and the Tyranny -- Page 66

The Tyranny under Hippias -- Death of Hipparchus -- Hippias Chanres His Policy -- Unrest in Athens -- The Exiles with Spartan Aid Assault the City -- Failure of the Exiles -- The Second Expedition -- Expulsion of the Tyrant

b. Cleisthenes's Struggle for Leadership -- Page 69 Quarrel between Cleísthenes and Isagoras -- Cleisthenes's Inoreased Power -- Scene of the Conflict -- The Ten Tribes -- Isagoras with Sparta Attempts to Set Up an Oligarchy -His Failure and Exile

c. The New Constitution -- Page 72 Antecedents of Cleisthenes -- The New Tribal Organization -Weakening of the classes -- Political Influence of the clans and Brotherhoods Destroyed -- The New Council of Five Hundred -- The Archonship -- The Areopagus -- The Ecclesia -- Law of Ostracism -- Its Relation to the Ecclesia -- The Strategi -The Helizea -- Cleisthenes's Constitution Not as Democratic as Commonly Supposed -- Did Not Conform to Gresk View of Demooracy

d. The Counoil of Five Hundred -- Page 81

An Adaptation of the Council of Four Hundred -- Origin of the old Council -- The Property Qualification for Membership -Various Powers and Influences - Permanence of cleisthenes's Reforms -- The Presidency -- The Head -- The Council as a Supervisory Body

- The Persian Wars and the Factional. Stmiggle -- Page 83 Two Forces Threatening the constitution -- Spartan Attempt to Restore Isagoras - - Attempts of Hippias to Regain the Tyranny -- The Ionian Revolt -- The Flight of Miltiades from the Chersonesus -- Antecedents of Aristeides -- Ambitions and Character of Themistocles -- Rivelry between the Two Statesmen -- Themistocles as Archon -- The Influence of Miltiades -Persian Preparations for Mar -- Hippias Leads Persia to Warathon -- Miltiades Defeats the Persian Hosts -- Digression on the Flashed Shield and Alcmaeonid Responsibility in the Matter -Disgrace and Death of Miltiades -- Aristeides as Archon -Previous Activities of Themistocles -- Ostrecism of the 0ligarchs -- Xanthippus and Aristeides Ostracised -- Themistocles Prepares for War -- Return of the Exiles -- Spartan Defeat at Thermopylae -- Hippias's Peace Offer Spurned by Athens 
f. The Areopagus -- Page 98

Its Early Development -- Draco Increases Its Powers -- Solon Raises the Body to the Position of Guardian of the Laws -Eclipse of the Areopagus under the Peisistratids -- Persian Wars Revive Its Influence -- An Unexpected Development

g. Development of the Ecclesia -- Page 101

Cooperation of Aristeides and Themistocles -- Themistocles's Naval Program -- Cimon's Entrance into Politics -- Aristeides Forms the Delian League and Assesses the Tribute -- He Urges the Commons to Live in the City and Control the fovernment -Cimon's Popularity -- Themistocles Ostracised -- Death of Aristeides -- Cimon Maintains the Influence of the Areopacus

h. Downfall of the Areopagus -- Page 106

Themistocles's Plot against the Areopagus -- Rising Power of Ephialtes -- Cimon Defeats the Plot -- Ephialtes Mistmusts the Areopagus -- Cimon Expands the Delian League -- Rise of Pericles -- Cimon Loses the Confidence of the Common People -- Ephialtes and Pericles Divest the Areopagus of its Most Important Powers - Cimon Ostracised; Ephialtes Assassinated; Pericles Supreme

i. State of the Democracy in B. C. 457 -- Page 110

Democretic Noture of the Constitution -- Power of the Ecclesia -- Strength of the Heliaea -- Strategi Supplant Archons as Leaders

j. Cleisthenes's Constitution in B. C. 457 -- Page 111 The Archonship -- Limitation of the Office -- The Areopagus -Council of Five Hundred -- The Ecclesia -- The Heliaea -- Its Position as Final Voice in Legal Disputes -- Leadership Passes to the Strategi

k. The Helizea -- Page 116

The Importance of the Heliaea -- Judicial Powers under the Monarchy -- The Junior Archons -- The Jury Court of the Nobles -- Solon Gives the Jury Courts to the Common People -- Expansion of the Judiciary under Peisistratus -- Influence of the Courts under Cleisthenes -- Jury Duty a Paid Service under Pericles -- The All-Embracing Authority of the Heliaea under Pericles

1. The Strategi -- Page 120

Reasons for the Rise of the Strategi - Legendary wilitary Power in Hands of the Monarch -- Creation of the Polemarch -The Generals under Draco -- Cleisthenes Connects them with the Tribal Set-Up -- Institution of the Ten Strategi -Waning Influence of the Polemarch -- Miltiades -- Military Organization at liarathon -- Themistocles Controls Public Affairs through the Generalship -- Themistooles, Aristeides, Cimon, Pericles as Strategi and Leaders -- Generalship at Time of Pericles 
m. Pericles as Leader of the State -- Page 125

His Antecedents -- The Attack on Cimon -- Opposition to the Areopagus -- His Public Policy -- Held His Power through the Office of Strategi -- Government by the First Citizen

IV WHY THE DEMOCRACY GRW AND TRIUMPHED -- PAGE 128

Nature of the Development of Democracy -- Growth of the Nobility at the Expense of Royalty -- Destruction of ijereditary Rights -Military Powers Stripped from the Monarch -- Struedle among the Nobles for Equality -- The Archons -- Growth of the Areopagus -The Code of Draco -- Development of Factionalism -- The Tyranny of Peisistratus -- Weakening of the Nobility -- The Persian Wars Develop Influence of the Lower Classes -- Control of Affeirs by the Naval Element -- Emancipation of the Ecclesia and Heliaea

\section{CONCLUSION -- PAGE 136}

Five Periods of Constitutional Development -- The Primitive Constitution -- Solon's Reforms -- Effect of the Tyranny under Peisistratus -- Cleisthenes's Constitution -- The Periclean Democracy -- The Seven Points of the Thesis Proved

GHONOLOGICAL TABLE -- PAGE 140

BIBLIOGRAPHY -- PAGE 142 
I N T R O D U C T I O N 
THE ATHENIAN CONSTITUTION FROM SOLON TO PERICLES

B. C. $594--$ B. C. 457

\section{INTRODUCTION}

Knowledge of the vonstitution of Athens previous to the time of Pericles is not clear because of the meagerness of source materials. Quite a bit of information is available concerning oertain phases of the question. Solon's reforms are discussed by most of the authorities, but no attempt is made by any writer to indicate the laws in their entirety. The usual reference is to the effect that the Solonian laws were based on the then existing constitution. What was that constitution? Without a knowledge of it attempts to reconstruct the final constitution of Solon are extremely difficult. When we search for it we find constitutionel data for the most part mixed with the legendary characters of earlier times; and it is only by a process of seperating the myth from the probable fact that we are able to piece together the fragmentary references to that docurnent. Again, Solon's constitution was supposed to have laid the foundation for later democratic supremacy. What is the basis for that assertion, and why was it necessary? 
All authorities agree that Cleisthenes prepared a new constitution for Athens, and that it made the democracy supreme. There is no doubt that he changed the tribal arrangement and thereby weakened the position of the nobility, but how was this related to the constitution as a whole? $\nu_{i d}$ it have any effect on the constitutional processes beyond the reorganization of the old council of Four Hundred? Except for detailed accounts of these two chenges, the sources give us very little to draw upon relative to the remainder of his reforms. Two questions foce the student in such an inquiry: 1) Did Cleisthenes increase the power of the Assembly? 2) What did he do to make the law courts function more broadly? Evidenoe seems to indicate that Cleisthenes's reforms took place gradually, and that the constitution did not come to its final democratic supremacy until the time of Pericles. What was the nature of his constitution after the reforms were completed by B. C. 503? Just how did it differ from the Solonian constitution which had been legally in effect under Peisistratus and his sons? Cleisthenes is said by his reforms to have made the common people supreme. Why, then, did the aristocratic element of Athens remain in ascendency for a period of sixteen years after the constitution became effective? Why was power not definitely curtailed before B. C. 487? Why did the Areopegus find it possible to conduct the administration for seventeen years after Thermopylae and Salamis as indicated by Aristotle? What did the constitution look like after the democratic supremacy in B. C. 457 ? 
The solution of all the foregoing problems is the purpose of this thesis. First, the legendary sources will be examined, and the constitution will be reconstructed as it stood when Solon began his reforms. Next, the reforms of Solon will be studied. Then follows the account of Peisistratus's regime, and the constitution will be reconstructed as it stood in the year B. C. 510 at the fall of Hippias. The reforms of Cleisthenes will be treated, and his constitution will be discussed. The development of the democracy under Themistocles and Aristides will follow, and, finally, the Cleisthenean constitution will be presented as it existed in B. C. 457 after the democratic triumph under Pericles.

Seven main points will be proved:

1. There was a constitution functioning when Solon came to power.

2. Solon's constitution was a constitution of the nobility, with all powers effectually checked.

3. Peisistratus did not destroy the constitution of Solon but operated under it, using the laws for his position as administrator with the old powers of the life-Archon.

4. Cleisthenes's reforms did not have the democratic effect that is commonly supposed, but took effect gradually.

5. Cleisthenes definitely increased the power of the popular assembly (Ecclesia).

6. The Assembly was the instrument by which complete democracy was achieved, and the Jury Courts (Heliaea) were used as a 
means of backing up the decisions of the Assembly.

7. The development of democracy was due to the rise of Athens commercially, and was a partial result of her imperialism. 
THE PRE-SOLONIAN CONSTITUTION 
PART I

THE PRE-SOIONIAN CONSTITUTION

Legendary Period -- Formation of the Constitution. The early period of Athenian history is filled with legendary characters. The memory of great men and their wonderful deeds lingered long after their deaths. As great legendary heroes such as Hercules and Theseus faded into the mists of the past, public patriotism surrounded them with a halo of wisdom and by degrees attributed to them all institutions which were found in existence years later. It is certain that no one man did or sould have done such deeds as are ascribed to these heroes, but to all such tales there is a foundation of fact. It is that foundation which reveals the early history of constitutional Athens, and reveals roughly the changing governmental processes of that city. Such are the materials with which we begin our study of the constitution which Solon found in existence whon he mede his famous law freeing the poor of their debts to be followed with a complete revision of the old laws. 
According to the legends the first government to be founded 1 was a system of royalty based upon a tribal system. By degrees the population of Attice became organized into a four-part tribal arrangement. Each tribe was divided into three groups celled Brotherhoods or Trittyes. Each Brotharhood a parently consisted of thirty family groups or clans, and although this ideal number probably fluctuated from time to time it is likely that every attempt was made to keep it intact. 2 Each of the clans could trace its ancestry to an ancient hero, an advantage which fomed the foundation of the later power of the nobility.

Under this primitive plan the community seems to have prospered. Ancient records indicate that victims of war or faction in other parts

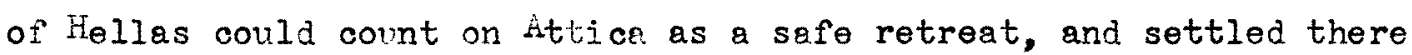
in large numbers. 3 Despite the growing influence of the community, however, unity was lacking. The people were scattered about the area

1. Heracleides, Epitome of Aristotle's Athenian Constitution, fragment 1 Since the beginning of Aristotle's work is lost, the fragments of Heracleides Epitome must be consulted for the opening sections of his work.

As the legend goes, Ion settled at Athens and witnessed the division of the inhabitants into four tribes under appointed tribal kings. Another account states that the first of the kings we re the four sons of Pandion who inherited his realm. Later legends ascribed the tribal arrangement to an imitation of the seasons of the year with each tribe further divided into three parts in order that there might be one part for each month in the year. Moreover each part corresponding to the month of a year was further divided into thirty parts each corresponding to a day in the year. See Aristotle, Athenian Constitution XII, 2; al so ierac. Epit., frag. 2,5

2. Herac. Enit., frag.5

3. Thucydides, I, 2 
and had difficulty in consulting their common interests, and these difficulties were further heightened by the occasional quarrels and fights among the sections.

It is at this point that the legendary hero, Theseus, enters the picture. Dismayed at the sight of such disorder, he is supposed to heve used his influence to consolidate all of Attica into one city-state with Athens as its center. In his effort at unity ho is said to heve visited each township and clan expounding his plon and its adventages. The comon folk and the poor reaily accepted the idea, and the more powerful were persuaded by the promise of a government without a king. The proposal was that the government become a democracy with Theseus as warlord and guardian of the laws. 3 Some inhabitants although opposed to the plan agroed to accept rather than refuse the great hero and perhaps be forced into submission. 4 Abolishing the council-chambers and maristracies of the surrounding cities, Theseus created a new single council-chamber and meeting place on a rocky hilltop in a central location and called the new site Athens. 5 Although individuals inight still enjoy all of their old rights of private property as before, they were henceforth compelled to acknowledge one and only one political center -Athens. Furthermore the later settlers of the region were granted

1. Plutarch, Theseus, 24

2. Ibid., 24

3. An imnortant term to be encountered more than once in this work

4. Plutarch, Theseus, 24

5. Thuc. II, I5 
citizenship thus increasing the population of the city to such an extent that an era of colonization followed. 1

Theseus is also supposed to have limited the monarohy to some extent. Having won the inhabitants of Attica to his point of view he laid aside his royal power and drew up a new form of government. 2 Although he is said to have established a democracy there is little evidence to support any change except the limiting of the monarchy in favor of the nobles. 3 The first important chenre is indicated in the breaking of the hereditary nature of the kingsinip. The legends in this respect are in agreement. It is represented that the sons of Theseus were not his immediate successors but remained as men of private station gaining the kingdom only after the death of one Menestheus. 4

During this shadowy period several important changes took place. We cen see the apearance of a class system with noblemen or Eupatrids in the ascendancy. These men had several important privileges. One of the most important was the control and care of the religious rites of the city with the corresponding authority to interpret the will of heaven. Also the Eupatrids had control of

1. Thuc. I, 2

2. Plut. Thes. 24

3. Thuc. II, 15

4. Plut. Thes. 35. Another account states that the house of Codrus, a late $r$ dynasty, was no longer utilized for the monarchy because they were thought to have lost the force and vitality believed a requisite for the kingship. Another view is to the effect that the house of Codrus abandoned the position of king for the new and important office of rehon. See Harac. Epit. frag. 7; also Arist. Ath. Const. III, 3 
the magistracies and recruited the membership from themselves. A further advantage growing out of the religious and legal administration was the duty of teaching the laws to the community, a former duty of the king. I These Eupatrids formed the faction known as the Plain. The other social oroups of the city were the peasants or Georgi who cultivated their own farms and had littlo time to give to the affairs of government; and the handioraftsmen or Demiurgi who gained their living through trade or commerce. 2 It seems that the limitation of the monarchy was to the advantage of the nobles. "Ne find them not only in possession of administrative knowledge, but also in possession of a jury court for their exclusive use. The record of the trial of the descendants of Alcmaeon ${ }^{3}$ states that this noble family was tried by jurymen selected according to noble birth. 4 Since the offense was a reli-. gious one it is likely that some connection with the court of the Areopagus existed since that body had authority in cases of sacrilege. 5 Another development -- more important perhaps -- is the fact that the monarchy becomes transformed from a hereditary monarchy to an eleotive monarchy, and that the kingship loses by degrees its administrative powers to the newly created official known as the Archon. This new office was also at first of a hereditary

1. Plut. Thes. 25

2. Cf. note 1. They had only reoently gained citizenship if immigrants at time of the institution of the law.

3. For the charge against the Al cmaeonids see the case of Cylon below pp. 13-14.

4. Arist. Ath. Const. I, I

5. See pp. $\frac{12,13 .}{12}$ 
nature, and increased so greatly in power that finally the reigning family abandoned the kingship for the Archonship. ${ }^{1}$

The king or Basilous had lost his powers by a slow and longdrawn-out process. In the period represented by Theseus the Basileus was commander in war and guardian of the laws ${ }^{2}$ and had in addition certain ancestral richts which were probably connected with the religious life of the community. 3 The institution of the council chamber under Theseus was probably the first check on the monarchy. 4 Another early diminution of the monarchical power came with the institution of the Polemar oh or warlord. Although it was alleged that the cowardice of the Basileus had necessitated the creation of the new office, 5 it is probable that the seizing of the military power was just another step in the effort of the Eupatrids to weaken the hereditary ruler. With the military duties went also the ancestral rights connected with war responsibilities. 6

The greatest encroachment on the powers of the Basileus, however, was the institution and development of the office of Archon. As was the case of the two other offices the Archonship was of a hereditary nature, and the increase in power became so great that finally the reigning family of the Medontids through the action of Codrus abandoned the kingship for the Archonship. ${ }^{7}$ That it was of

1. Arist. Ath. Const. III, 3

2. Plut. Thes. 24

3. Arist. Ath. Const. III, 3

4. See page 7

5. Arist. Ath. Const. III, 2

6. Arist. Ath. Const. III, 3

7. Ibid. 
rather late institution is seen in the fact that no ancestral rites were ever administered by that officer, but all festivals in his charge were merely duties added after the office had come into being. ${ }^{1}$

As the nobles continued to increase in power the Archonship became divorced from the possession of one family and was opened to the nobility on the basis of birth and wealth as had been the case with the kingship. Birth was still all important, but we see wealth as an added requirement thus undermining the privileges of birth. As first instituted the office was held for life as was the case with the Basileus and Polemarch, but some time during this period the term of service for these offices was reduced from 3

a life-time job to a term of ten years. This time of service was reduced further to a one-year term in a relatively short time, and there was no privilege of relection although at first this was hardly the case. 4 It is at this final stage that the Archonship emerges from legend.

It was at this same time (about B. C. 650-630) that the powers of the Archons, as the Basileus, Polemarch and. Archon Enonymus were collectivelyknown, were restricted further with the creation of six minor Archons known as the Thesmothetae or Legislators. As was the case of the Archon Eponymus these officers were qualified by birth and wealth, and could never hold office for more than one year. ${ }^{6}$

1. Arist. Ath. Const. III, 3

2. Ibid., III, 2

3. Ibid., III,I

4. Ibid., III, 4

5. Desipnation of the chief administrative Archon

6. Ibid., III, 4 
These six men acted as assistants for the three major Archons each of which had two of the lhesmothetae to serve him. To these six officers went a major part of the judicial functions of the Archons, including the public recording of the ordinances in order that they might be preserved for the trial of litigants. I They had the further power to give final judgnents in lawsuits thus further undermining the powers of the major Archons. 2 We further notice that the election of the entire group of nine Archons was in the hands of the hreopagus which issued a summons selecting each candidate independently and commissioning him to hold office for one year. 3 Despite these counter-checks, the nine Archons remained strong, and in the time of cylon discharged most public functions of the state. 4

The Areopagus was a judicial and executive body which consisted entirely of membership from the nobility. The first trace of its existence is seen in the council-chamber as instituted by Theseus, which certainly included among its members the nobility although it is by no means certain that the other fections were excluded. In spite of our uncertainty concerning the original method of choosing the membership, it is as a body of ex-Archons that the Areopagus first meets us in the sources. Its original powers seem to have been the exercising of moral control over the

\footnotetext{
1. Arist. Ath. Const. III, 4

2. Ibid., III, 5

3. Ibid., VIII, 2

4. Thuc. I, 126

5. See page 7
} 
state in wich capacity it heard cases of sacrilege ${ }^{1}$ and was enabled to inflict penalties and fines upon offenders against public order, from which decisions there was no appeal.

The real strength of the Areopogus was of an administrative nature, however. Officially the Council (as the Areopagus was frequently called) was given the power of guarding the laws -- a duty which had formerly rested with the Basileus. 3 Actually in carrying out this duty the Areopacus reached the point where it administered the greatest number and most important affairs of state. 4 Since each member was a former law maker and held his membership for life, 5 the body rapidly gained in influence until it riveled the rohons in power. Indeed, it not only chose the Archons; it was possibly the source of supply for the noblemen's jury court also.

This process of dividing the administrative power was not a peaceful process. There is no doubt that much strife must have occurred at each new departure from the old and accepted customs. It is very likely that on more than one occasion some ambitious nobleman tried to seize for himself all of the power of the state. One such case is recorded in the annals of Athens, and because of its future political significance must be releted at this time.

1. Arist. Ath. Const. I, I

2. Ibid., III, 6

3. See page 7

4. Arist. AtB. Const. III, 6

5. Ibid..

6. Arist. Ath. Const. I, I 
An Athenian named Cylon had been a winner at the Olympic games and had utilized his popularity to gain a following of other young men in the city. Putting on a brave air he attempted to seize the oitadel. ${ }^{1}$ Receiving word of the act, the citizens came from the surrounding country and laid siege to the place. $\hat{A}_{S}$ time went on the citizens wearied of the affair and left, entmusting everything to the nine Archons who were given "plenary powers to arrange everything according to their good judgment." 2

As the siege progressed Cylon and his brother made their escape, but the others facing starvation took refuge in the temple. Wegacles, the Archon Eponymus and member of the powerful family of the Alcmaeonids, persueded the fugitives to surrender and stend trial for their offense. 3 Under the law Cylon's followers were liable for any penalty except death and conseguentl the men surrendered themselves. Nevertheless Megacles and his fellow Archons slew them, and even those who sought sanctuary at the altar of the goddess were not spared. 4 As their defense the Alanaeonids related that the insurrectionists had fastened a braided thread to the imege of the goddess and had kept hold of it; but that on their way down the thread had broken of its own accord. Gonsiderinm this a judgment of rejection on the nart of the goddess Alcmaeor and his followers killed them. 5 In spite of this defense the Alcmaeonids were unable to clear themselves of

1. Herodotus, V, 71

2. Thuc. I, 126

3. Ibid.

4. Herodotus, $V, 71$

5. Plut. solon, XII, 1 
the charge and they and their descendents were held to be under the blood taint of the goddess whom they had desecrated. The descendants of cylon continued the charge and the polluted family was constantly being threatened with expulsion, and just as persistantly returned whenever the sentence of exile was passed upon them. 1

While the nobles were destroying the power of the king, dividing up the powers of the Archonship, and fighting among themselves, they were also oppressing the common people. It seems that with the passage of time, as the nobles became richer and the commons became poorer, all debts became secured on land or failing that on liens secured on the person. ${ }^{2}$ As the nobles gradually secured possession of the land, Attica became divided among only a few owners and the commons were passing into a condition of serfiom which closely resembled slavery. 3 Finally in exasperation at being mistreated and perhaps cheated, the commons rose up in revolt and apparently demanded a code of law in order that they might know the law as well as their noble masters. This task fell upon Draco, and it is his modification of the then existing constitution that was the law of the land when Solon came into power.

The Reforms of Draco. The principal work of Draco seems to have been the reforming of the then existing constitution the nature of which has been previously discussed. 4 The major portion of the

1. Thuc. I, 126

2. Arist. Ath. Const. IV, 4

3. Ibid.

4. Arist. Politics, II, ix, 9 
work undoubtedly consisted of a written law oode which supplemented the constitution and made available to the people knowledge of the Iaws -- a privilege previously in the hands of the Eupatrids alone. It is probable that the code was written in response to immediate difficulties developing out of the factional strife.

In the sources there are allusions to the Archonship and the Areopagus thus confirming their position in an earlier constitution. Citizenship had been bestowed on all persons who were able to provide themselves with arms, presumably as a guarantee of their ability to help protect the state in times of stress, and these citizens elected the nine Archons from among a group of persons each of whom owned an unencumbered estate worth at least ten minae. 2 Each outgoing Archon was required to give bail until an official check had been made of his accounts as an officer. 3 According to Solon's laws the Areopagus was apparently functioning before his time especially with respect to cases involving murder or homicide. From this it appears that the Areopagus was included in the Draconian code. ${ }^{4}$

The Eoclesia seems also to have been in existence at the time of Draco although nothing is known of the nature of its duties. 5 This body presents an interesting problem in connection with Solon. He

1. Arist. Ath. Const. XLI, 2

2. Ibid., IV, 1-2

3. Ibid., IV, 2

4. Plut. Solon, XIX, 2-3

5. Arist. Ath. Const. IV, 3 
is mentioned by Aristotle as the first leader of the people, 1 and the leader of the people usually functioned in tho Ecclesia. Does this mean that there was no organizetion of the people before his time? Not necessarily. The body might have been a meting of the nobles to discuss the proposed actions of the Areopagus or Archons -- in other words somewhat like the Uouncil of Four Iundred; but it might just as well have been instituted by Draco. Solon's Code followed that of Draco by about twenty-seven years so that he (Solon) could quite easily have been leader of the people in Draco's time and have worked under his supervision. Thus it could have been an organization of the people, and a concession to them for their lack of activity in the government.

Another new body is the above-mentioned Council of Four Hundred. It consisted of four hundred men chosen from the citizen body by lot, and all citizens thirty years of age or above participated in the election. The body was probably presided over by an Archon thus bringing the number up to four hundred and one. No person was permitted to hold office twice until the lot had been extended through the entire list of eligible citizens; and an additional oprortunity for service might again arise as the lot was cast again fron the beginning. ${ }^{3}$ It seems, however, that no person might serve for nore than two years in his life. Nothing is definitely known of the nature

1. Arist. Ath. Const. II, 1-2

2. Ibid., IV, 3

3. Ibid. 
of the Council's business at this time. It may be that the size of the Ecclesia had made necessary the creation of this new body as a committee for the purpose of shaping up the business to come before the popular group. "Ne are told that failure to attend the meetings of either Council or Ecolesia incurred a fine against the offending councillor, and that the fine was proportional to the wealth of the member. Since there is no mention of a fine for the Thetes (the poorer class), and it is inconceivable that the poorer classes would get off scot-free, it is evident that they were excluded from membership. If this is the case, the probable function of the Council was to oheck the activities of the Ecclesia which did include the Thetes.

The most famous part of Draco's work, however, is his severe code of law which imposed the death penalty for most infractions including idleness, theft, sacrilege, or murder. ${ }^{2}$ The requirement of such an extreme penalty for a transgression such as stealing salad - or fruit seemed as unreasonable then as it does now; yet, when the citizens asked Draco why he required death for most offenses, he stated that in his opinion the lesser ones were deserving of death while for greater offenses no heavier penalty was possible. ${ }^{3}$ Such severity seems to indicate a serious strugrle arising out of oppression in which the commons goined certain adventages such as

1. Arist. Ath. Const. IV, 3

2. Plut. Solon, XVII

3. Ibid. 
admission to minor offices, perhaps membership in the Ecolesia, and beyond doubt a written code. In return, however, the Thetes may have submitted to a check on the Eoclesia by means of the Council of Four Hundred, 2 and a harsh code as a guarantee against a further uprising.

The Constitution of Draco. Although Aristotle states that Draco was author of a constitution as well as a law code, ${ }^{3}$ not a great deal is known about the former. Since Aristotle states thet there is nothing about the laws worthy of mention except their severity, 4 it is probable that the general lines of the constitution remained much as he found them. The whole framework was built upon a class system consisting of the Eupatrids, the Georgi, and the Demiurgi, each of which was identified with the factions of the Plain, the Hill, and the Shore respectively. Appointment to office went by birth, and wealth was beginning to play an increasing role in influencing the deliberative bodies. 5

Of the offices the Archonship was well established, and controlled the administration subject to supervision of the Areopagus although that body no longer retained the right to elect the officers. 6 It is probable that the Basileus presided over the Areopagus even as the Archon Eponymus presided over the Counoil of Four Hundred. In Draco's time the Archons had separate meeting places: the Basileus

1. Arist. Ath. Const. IV, 1-2

2. Plut. Solon, XIX

3. Arist. Polit. II, ix, 1

4. Ibid., II, ix, 9

5. Thetes barred from Council; Council dominates Ecclesia

6. Pist. Ath. Const. IV, 1-2 
near the Town Hall or Bucolium, the Polemarch in the Epilyoeum, the Archon Eponymus in the President's Hall, and the Thesmothetae in the Legislator's Court. ${ }^{1}$

The Aroopagus controlled the administration of affairs through its power of moral censorship, and was the center of power in the land since it also acted as a court of appeal against the magistrates. As guardian of the laws the Areopagus was enabled to keep a watoh on the activities of the Archons holding them to the letter of the lew. Should the Archons evade such supervision a person unjustly treated had the right of aprearing before the Areopagites stating the law in question and obtaining justice. " The rreopagus was thus a sort of court of appeal, and in that capacity was rapidly forging ahead to a position of eminence.

There was also an Assembly (the Ecclesia) in existence although not very strong, and it was rhaps dominated by the nobility. Although nowhere directly mentioned, the assurance of continuation of most features of the old constitution indicates the existence of jury courts; but it is probably true that they were as yet restricted to the nobles for their exclusive use. That this is likely is substantiated by the growth of the court functions of the Hreopagus and the development of the duties of the Thesmothetae and other Archons. The Council of Four Hundred was in operation at this time and was probably created to act as a check on the Ecclesia

1. Arist. Ath. Const. III, 5

2. Ibid., IV, 4 
should the commons at any time threaten to get out of hand. It excluded the Thetes as the commons were known, and prepared the business for the Ecclesia without which preparation that body was seriously hampered.

Finally we find provision for the election of Generals by the citizen body. These officers were chosen from among the more wealthy nembers of the state since it was required that each successful candidate must ow property worth not less than one hundred minae. A further requirement was the possession of legitimate sons over ten years of age -- a provision the significance of which is not clear.

In general the constitution with its powerful Archonship, Areopagus, and Council of Four Hundred appears to be heavily aristocratic, and the Ecolesia and whatever other power the people had gained seems to have boen effectually checked.

1. Arist. Ath. Const. IV, 1-2. Under the laws of Solon the generalship could not be held by the Thetes (those. of lowest property qualifications). For a description of these classes see p. 28 . 
THE SOLONIAN CONSTITUTION 
PART II

\section{THE SOLONIAN CONSTITUTION}

Failure of the Draconian Reforms. Draco's harsh code did not settle the issue between Eupatrids, Demiurgi, and Georgi. Although the Georgi had gained definite knowledge of the laws and had received a limited representation in the government they were dissatisfied. The constitution was in all respects an oligarchy, and the Eupatrids had by degrees reduced owmership of the land to a select few. 1 Most Georgi thus found themselves reduced to the position of tenants, and were reguired to pey five-sixths of their gain through farming. 2 The payment of this yearly sum was secured through the person of a tenant or a nember or members of his family, and failure to pay a debt made one liable to arrest. ${ }^{3}$ If a tenant were unable to meet his obligation, he or his family could be sold into slevery for the debt. In such an event the debtor might either becone a slave at home or be sold into foreign lands. Frecuently debtors were forced to sell their own children to preserve their rreedom or, if able to escape, go into exile. 4 The real cause of

1. Aristotle, Athenian Constitution, II, I

2. Ibid., II, $\overline{2}$

3. Ibid.

4. PIutarch, Solon, XIII, 2 
the previous uprising in the time of $\mathrm{\nu}_{\mathrm{raco}},^{1}$ the lebt situation, had not been affected, and with the Georgi threatened by virtual serfdom the social struggle continued.

By B. C. 594 two definite frotions had developed in Athens: the Plain representing the noble tupatrids, and the $\forall i l l$ consisting of the cormon Georgi. With these two groups arrayed against each other the issue at stake seemed to be democracy versus oligarchy. Meanwile another group was also interested, the Shore, representing the Demiurgi or merchant faction. ${ }^{2}$ The Shore-men preferred a mixed form of government and were sufficiently strong to prevent either of the other two parties from gaining the ascendency. 3 Using their strategic position the Demiurgi threw their influence where it seerned to yield the greatest benefit for themselves in the form of either admission to the offices or the privilege of citizenship. So serious had the struggle become that the only solution to the situation seemed to $l i \theta$ in a tyranny, 4 and after an apparently exhausting strugele all parties in searoh for a means of compromise found their man in solon.

Solon had gained fame as a settler of quarrels by his handing of the quarrel of the descendants of Cylon and Megacles over the blood curse. 5 Although apparently able to maintain themselves in

1. The revolt subsequent to Cylon's ottempt at tyranny. See p. 15

2. The three groups, Plain Hill and Shore, were named after the geographical location of their acherents' place of residence.

3. Plut. Solon, XIII, 1

4. Ibid., XIII, 2

5. See pages $14-15$ 
Athens for sone time after the deed, Megacles's family (the Alcmaeonids) was unable to withstand the religious accusation and finally submitted to banishment. I They were evidently too powerful to bo kept out of the city permanently for we soon find them back in the city disputing the leadership with the descendants of cylon who had recovered their strength. By about B. C. 599 the quarrel had reached its height and the entire city had divided itself into two factions supporting one family or the other. ${ }^{2}$ Solon was at this time in high repute ${ }^{3}$ probably in consequence of his fame as a poet, and possibly as a result of some connection with the reforms of 1 reco. ${ }^{4}$ Furthermore he was a member of the illustrious Medontid family, 5 and his descent from the superlatively good Codrus enhanced his eminent reputation. Judging from his later career it is likely that he had refrained from taking sides in the quarrel.

At any rate Solon together with the noblest of the Athenians succeeded in persuading the accused family to submit to a trial of , three hundred jurors selected from the nobility and to abide by their decision. 6 The Al cmaeonids were found guilty of sacrilege by the jury and in consequence of the verdict the family was condemned to everlasting banishment, and the bodies of the perpetrators

1. Heracleides, Epitome of Aristotle's Athenian Constitution, frag. 8

2. Plut. Solon, XII, 2

3. Ibid.

4. See pp. 16-17

5. Plut. Solon, I

6. Ibid., YII, 2 
of the crime of B. C. 632 were cast out of their tombs and taken to a spot without the aity.

Solon was in a singularly favorable position to challenge the admiration of his fellow-citizens. By birth he was of the foremost family in the city, ${ }^{2}$ and by wealth belonged to the upper middle class. 3 In addition he had espoused the cause of the commons and had defended them to some extent. ${ }^{4}$ His composition of an elegy -"in which he does battle on behalf of each party against the other and acts as mediator, and after this exhorts them jointly to stop the quarrel that provailed between them" ${ }^{5}$-- created further confidence in himself. He also offered other sound advice looking toward a reasonable solution of the social problem. 'ine populace felt that anything was preferable to their situation; all factions, in fact, favored a tyranny under Solon and offered the power to him. When he refused the offer, he was chosen Archon and made emergency 6 administrator.

He was chosen Archon to succeed Philombrotus, and made mediator and legislator for the crisis, the rich accepting him readily because he was well-to-do, and the poor because he was honest. It is also said that a certain utterance of his which was current before his election, to the effect that equality bred no war, pleased both the men of substance end those who had none; the former expecting to have equality based on worth and excellence, the latter on measure and count.

1. Arist. Ath. Const. I, I

2. Plut. Solon, I

3. Arist. Politics, IV, ix, 10

4. Arist. Ath. Const. XXVIII, 2; see also pp. 16-17

5. Ibid., $\bar{\nabla}, 1-2$

6. Plut. Solon, XIV, 2 
Therefore both parties were in high hopes, and their chief men persistantly recommended a tyranny to Solon, and tried to persuade him to seize the city all the more confidently now that he had it completely in his power. Many citizens, too who belonged to neither party, seeing that it would be a laborious and difficult matter to effect $a$ change by megns of argument and law, were not reluctant to have one man, the jusfest and wisest of all, put at the heed of the state.

The Solonian Reforms. As Archon Eponymus Solon was entrusted with the entire government and was given full power to make chenges in the laws which would make peace between the rival factions. In his actions he was quite independent, showing regard neither for the rich nor for his supporters. ${ }^{2}$ His first act was a demonstration of this free hand which he had gained in public affairs. Attacking the root of the situation Solon cencelled all debts, public and private, and decreed that in the future no more loans could be secured on the person of the borrower or his family ${ }^{3}$ This act, while not a complete solution to the debt problem, did alleviate the situation in two ways: it made future serfdom impossible, and the debt oancellation gave everyone a new start. Politicelly it was a move definitely in favor of the people, but approval was not immediately forthcoming.

The factions as a whole were dissatisfied with Solon's action. Many of the Eupatrids having become poor were filled with resentment, and many of the Georgi were dissatisfied because they had

1. Plut. Solon, XIV, 2-3

2. Ibid., XV, 1

3. Arist. Ath. Const. VI, 1 
expected a redistribution of wealth instead of a mere cancellation of debt. ${ }^{1}$ In addition there was a suspicion that he had used the law for his personal benefit since it was known that some of his personal friends had greatly profited from the decree. ${ }^{2}$ This reaction soon passed, however, when the factions begen to realize that Solon, if he had wished, could easily have used his opportunity to reduce either the Hill or the Plain to complet subjugation and thereby have won for hinself a tyranny. 3 seeing that the action had been taken for the public good and that Solon instead of allying himself with one of the factions had made every effort to bring about concord among them, ${ }^{4}$ the citizens further empowered him to alter the constitution so that their differences might be composed. 5 In this respect he was given a free hand so that he could alter magistracies, assemblies, courts, and councils; moreover he was to "fix thd property qualification for each of these, their numbers, and their times of meeting, abrogating and maintaining existing institutions at his pleasure."

1. PIut. Solon, XVI, I-2

2. Arist. Ath. Const. VI, 2-3. It is possible that Solon did this deliberately in order to gain support for his further measures. It may be that some of these friends were of the faction of the Shore, and that he took this means to win their party to his support. It so happened that he discussed the plan with some friends before taking action; and those friends using the inside information exchanged their threatened debt holdings for land thus emerging with a handsome increase in wealth. Solon was much blamed for this, but his supporters defended him on the ground that he misjudged the honor of his friends. See Plut. Moralia, $807 \mathrm{E}$; also Arist. Ath. Const. VI, 2-3

3. Arist. Ath. Const. VI, 3-4

4. Plut. Mor. $805 \mathrm{E}$

5. Diogenes Laertius, Solon, I, 61-62

6. Plut. Solon, XVI, 3 
One of his first chenges was the abolition of the ordinances of Draco except for those relating to homicide. ${ }^{1}$ The reason for this wholesale elimination of the Code was the severity of its terms and the heaviness of its penalties. The almost universal punishment of death for each infraction was undoubtedly unpopvlar with the masses, and was very likely another move for popular sunport. 2

It was Solon's desire to keep the maristracies in the hands of the wealthy, but he did not think it proper to exclude the poorer classes from other participation in the government as had formerly been the case. 3 He therefore reorganized the class system along the lines previously established for the Council of Four Hundred and the Generals, "basing the divisions eccording to wealth gained from produce of the land. Four now groups were now created: 1) the Pentroosiomedimni; 2) the Hippes; 3) the Zeugitae; and 4) the Thetes. The Pentacosiomedimni were those persons who enjoyed a yearly production of five hundred measures either wet or dry, and to them was entrusted the carrying out of magistral duties. The Hippes consisted of thos whose yoarly production amounted to three hundred measures while the Zeugitae were all those with an annual yield of two hundred measures. Theoretically the Iippes were those able to equip and maintain a horse for battle purposes

1. Arist. Ath. Const. VII, 1

2. Plut. Solon, XVII

3. Ibid., XVIII, 1

4. See pages $17-18,21$ 
while the Zeugitae were of a group not so well off yet able to provide at call a team of horses for military use. These two groups were also amitted to some of the offices in the rovernment. ${ }^{1}$ The Thetes vere those persons who were unable to meet the above production requirements and consisted for the most part of the laboring class. They were not permitted to hold office, but did have the privilege of membership in the Ecclesta and Heliaea.

Solon then made all officers elective by lot according to the assesments of the above system. ${ }^{3}$ Althouch the Thetes were barred from office they could by increasing their production be advenced to a hicher classification and thus gain admission to the offices. 4 Similarly, one could advance or fall under the production system. Practical Results of the Keforms. The reforms of Solon put an end to oligarchy and liberated the lower classes from slavery. No longer could a member of the lower class be reduced to serfdom by failure to meet his obligations. 5 By basing class divisions on the produce of land, Solo destroyed the privileges of birth, and substituted wealth as a bese for aristocracy. From this point of view Solon took one step toward democracy since he mare it possible for a person to alvence fro one classification to another by increasing or decreasing the amount of his yearly income from the land. Br making

1. Arist. Polit. II, ix, 4

2. Plut. Solon, XVIII, 1-2

3. Arist. Ath. Const. VIII, 1

4. Ibid., VII, 4

5. Arist. Polit. II, ix, 2 
the Jury Courts available to the Thetes Solon also materially aided the cause of democracy since he placed all classes on an equal footing at law with the element of the lot removing aristocratic control.

Yet the Solonian constitution was strongly aristocratic. The effectiveness of the Jury Courts was somewhat nullified by the difficulty of getting the Thetes who lived at a distance to come to town and serve. I similar ciroumstance weakened the position of the Thetes in the Ecclesia, while the Council of Four Hundred (strengthened by Solon) through its control of agenda and its exclusion of the hetes further strengthened the hand of the upper classes. Most important was the fect that all offices were held by the nobles and the wealthy, and no one of the l'hetes was eligible for such service. With the courts unavailable through circumstance, the Ecclesia subject to the will of the Council, the Council barring Thetes, an Areopagus recruited from Archons, and the magistracies open only to upper-olass men, the aristocratic principle remained. The only difference was a change from aristocracy of birth to aristocracy of wealth. The onstitution of Solon. Solon besed his constitution squarely upon the structure provided by Draco. In comparince the two we find the same administrative and deliberative bodies in each government. The four tribes, the Archons, Areopagus, Ecclesia, 1. Arist. Polit. II, ix, 2 . 
Council, and Heliaea are conmon to both; and no revolutionary differences are to be noted in any case. His refoms were really a compromise in which the lower classes were given as much power as the occasion warranted, but no more.

The tribal system remained untouched, and the unper classes continued to rule as before. There were still four tribes and four tribal kings, and each tribe had three brotherhoods each. We can see evidence of the rrowth of commercial relations in the time of Solon, for we find that the shipping is controlled by the tribes with each tribe having twelve ship-hoards or Naucrariae. These līaucrariae were forty-èight administrative districts for taxation, and each provided equipment for one battleship. Over the Naucrariae were appointed Ship-Commissioners (Naucreri) who "appointed for the levies and expenditures that, were made." For this purpose Ship Commission Funds had been established to defray expenses of commerce. ${ }^{2}$ A further duty of the tribes wes the selecting of ten candidates each for the Archonship by rote from which group of forty the election of nine was to take rlace by lot. All other offices of state were chosen in a similar menner. 3 Since the tribes were subject for the most part to pressure from the Eupatrids through the Brotherhoods, the aristocracy clearly dominated tribal relations to the governmental set-up.

1. Arist. Ath. Const. VIII, 3

2. Ibid.

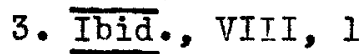


The four class divisions of the Pentacosiomedimni, Hippes, Zeugitae, and Thetes were an attempt to overthrow the power and influence of the Bupatrids, and as such supplanted the tribal influence to some degree. The five hundred, three hundred, and two hundred measure standard was a distinct blow at the Eupatrids since many persons of doubtful lineage or even naturalized citizens were now eligible for the highest offices in the land save the Archonship. But even with this handicap the most powerful families such as the Medontids and Alcmaeonids continued to lead since the wealth requirement only served to increase their influence. Generally speaking the addition of wealth to birth as a requirement for the Archonship only served to place that office in stronger hands and thus to make the office itself stronger.

So the class reforms seemed to provide the ominous possibility of a struggle for supremacy in which the more powerful nobles might be tempted to aim at a tyranny. As we shall later see, this possibility developed into a reality. On the other hand many nobles, reduced to poverty by the force of the debt cancellation, were in desperate straits and only needed a leader to cause trouble. Similarly the Thetes, excluded from office and restrained by circumstance from exercising any of their constitutional rights, were sure to continue the strife shovid a leader be found for them. Should these two groups be broucht together, a trial of strength would be certain. 
Concerning the "naturalization" of oitizens Solon set up two conditions: I) those permanently exiled from their own country, or 2) those moving to Athens with their entire family to ply a trade could gain citizenship. ${ }^{l}$ His purpose was to attract to Athens those persons who would not only make useful citizens but would also offer full assurance of becoming citizens. It was felt that those who had been exiled for life would welcome the opportunity of citizenship while those who had shown by their determination of cutting all ties with their former country would be equally deserving of the franchise.2 Foreseeing the tendency of Athens toward factionalism and noting a tendency of some citizens to be indifferent to such quarrels, Solon enacted a special law decreeing that anyone refusine to take sides in case of party strife should and would be disfranchised and lose his membership in the state. 3 By this measure he hoped to maintain complete civic interest in the affairs of state, and also to make it possible for every member of the city to indicate his stand in a quarrel. He thus made certain that no faction weak in numbers might gain control of affairs through indifference of the citizenry, and he probably hoped that the device would prevent the establishment of a tyranny through public inertia.

The Archonship remained aristocratic as before, 4 although election of those officials was taken out of the hands of the

1. Plut. Solon, XXIV, 2

2. Ibid.

3. Arist. Ath. Const. VIII, 5

4. Arist. Polit. II, ix, 2 
Areopagus and placed upon a lot basis. The fact that they were chosen from a preliminary list chosen by the tribes, and were aocountable to the people does not alter the fact that the magistracies still remained in the hands of the wealthy upper class. I Nevertheless the people under supervision of the Ecclesia chose these magistrates, and more important required an account of their year's activities when they went out of office. 2 choice of the Archons in the preliminary tribal selection was restricted to the " Pentacosiomedimi and Hippes thus disbarring the Zeugitae and Thetes from legal access to the office. ${ }^{3}$ Solon was responsible for several innovations including the rule that all of the Archons should meet in private conference ${ }^{4}$ in the Legislators' court. 5 Such conferences were doubtless instituted to facilitate the coordination of duties of the offices partionlarly relations between the major Archons and the Thesmothetae. A law had also been passed. forbidding the exportation of any product except oil, and it was the function to pronounce curses upon anyone who violated the ordinance. Fajlure to do so inourred a fine of one hundred drachmas which the guilty Archon must pay into the public treasury. ${ }^{6}$ To secure fidelity to the laws each Archon was swom to obey all of the laws, and failure to do so placed upon him the obligation to dedicate a gold statue of a man as a penalty for his transgression. 7

1. Arist. Ath. Const. VIII, 1

2. Arist. Polit.II, ix, 4; elso III, vi, 7

3. Arist. Ath. Const. XXVI, 2

4. Diog. Laert. Solon, I, 58

5. Arist. Ath. Const. III, 5

6. Plut. Solon, XXIV, 1

7. Arist. Ath. Const. VII, 1-2 
The Areopagus, although it lost the power to supervise the election of Archons, really became more powerful than before and was definitely in the position of guardian of the laws, thus keeping watch over the most important affairs of the state. ${ }^{1}$. This meant that most public affairs were subject to its cognizance with the privilege of correcting offenders against the constitution, and to fine and punish in sorious cases. The Areopagites also exercised the right to try those persons milty of attempt to put down the democracy. 2 The Areopagus also had supervision sver the public morals, ${ }^{3}$ and had charge of murder cases (homicide). ${ }^{4}$ This moral power could have grest potential advantage, and Solon directed it against the lejsured class. Realizing that the land was barely able to support the inhabitants and was unable to support an idle multitude, he made all trades worthy of dignity; the Areopagus was ordered to investigate every man's means of livelihood, and recommended punishment for those who were discovered to have no occupation. 5 With so many important duties and privileges it is not strange that the Areopagus easily surpassed all other councils in excellence.6

As was formerly the case, the membership consisted exclusively of ex-Archons ${ }^{7}$ who had vroved their fitness for the place, and that

1. Plut. Solon, XIX, 2

2. Arist. Ath. Const. VIII, 4

3. Isocrates, Areopagiticus, 37

4. Arist. Ath. Const. XVI, 8

5. Plut. Solon, XXII, 3

6. Isocrates, Areopariticus, 37

7. Plut, Solon, XIX, I 
Membership was retained for 1 ife. ${ }^{1}$ The membership was consequently recruited from those of noble birth ${ }^{2}$ making the body inevitably an oligarchic group. 3 Nevertheless it maintained such a reputation of excellence and did its job so well that it was considered by all to be without equal, this to such an extent that even in a later age it seened natural to refer to the body simply as "the council." 4 With such a rentation it is not surprising to find an extraordinary degree of trust imposed upon it. This confidence was so great that it could dispose of public moneys without a statement of the reason for the expenditure. 5 But with all this halo of righteousness the Areopagites were not impeccable, and provision was probably made for removal under certain circumstances. ${ }^{6}$ Among such instances were doubtlessly included offenses involving forfeiture of oitizenship, exile, or perhaps inability to perform the duties of office in an acceptable manner. ${ }^{7}$ It is also interesting to note that Areopagites probably were required to ask leave of absence when departing from the city for any length of time. ${ }^{8}$ This indicates the indispensibility of the members and is a further proof of the importance of the Areopagus in Solon's tine. 9

1. Arist. Ath. Const. III, 6

2. Isoc. Areop. 37

3. Arist. Polit. II, ix, 2

4. Cicero, De Natura Deorum, II, 29

5. Arist. Ath. Const. VIII, 4

6. Plut. Mor. $790 \mathrm{C}$

7. See pp. $\overline{24}, 33$

8. Plut. Solon, XXV, 5

9. The situation is similar to the law prohibiting the Tribunes from leeving Rome during their term of office. 
Concerning the Assembly of the people (the Ecclesia) little is definitely known of its duties at this time. Beyond the fact that it is in existence and includes the entire citizen body (even the Thetes) nothing else can definitely be said. I Potentially the organization was the bulwark of the common people, and at a later time was destined to form the channel through which the people were to achieve democracy.

The council of Four Hundred was created by Solon to act as a check on the common people, and its initial duty seems to have been the preparation of business for them -- in other words a comnittee comparable to the great Congressional comnittees rolled into one. It can be traced back to Draco in such a capacity and was possibly created by Solon then. 2 After freeing the Thetes from their debt slavery, Solon began to notice their restlessness, and the duties of the council of Four Hundred were enlarged. As had previously been the case the membership was recruited from the four tribes with one hundred from each. ${ }^{3}$ It is likely that it was at this time that the council received the sovereign power to pass sentences of fine, imprisonment and death as well as the right to reject officers whose qualifications were not in order. 4 Its most important power was its right to deliberate on public matters before the Ecclesia did, and under Solon this right was expanded to the

1. See pp. 16-17, 20

2. See p. 17

3. Plut. Solon, XIX, I

4. Arist. Ath. Const. XLV, 1-3 
extent that no matter could come before the Ecclesia without action by the Council. 1 Since the Council had such close relation to the tribal set up and supervised the actions of the Ecclesia, it is entirely likely that the tribes acted through it when making the preliminary selection of candidates for the Archonship. With these additional powers Solon had raised the Council of Four Hundred to a point where it was a definite power in the state, and acting as an additional check on the Thetes since none of this classification was eligible for membership.?

The really democratic feature of the constitution was the Heliaea. 3 Though probably based on the older Jury body which had operated exclusively for the benefit of the nobility, ${ }^{4}$ the new system bore no vestige of the ancient aristocratic set-up in its operation. The new Heliaea were the real center of Solon's democratic reforms, for the lower clesses were admitted with the nobler groups, and every citizen had a right of appeal to them. 5 This right of appeal, recognized by the Athenians as the foundation stone of their democracy, ${ }^{6}$ was of highest importance for cases assigned to the magistrates, since the decision could be appealed to the Heliaea if anyone so desired. ${ }^{7}$ This would logically make the law courts all-powerful.

1. Plut. Solon, XIX, 2

2. See pp. 2I, 29

3. Arist. Polit. II, ix, 2

4. Plut. Solon, XII; See also p. 24

5. Ibid. XVIII, 1-2

6. Arist. Polit. II, ix, 3

7. Plut. Solon, XVIII, 2 
But at the time the potential strength of the courts was little noticed; indeed, Aristotle was of the opinion that the Heliaea did not found the democracy. ${ }^{1}$ The Heliaea did not bring about democratio government; that remained well in the future. Theoretically the Juries were democratic, ${ }^{2}$ but the people were not close at hand and thus were unable to serve with any degree of regularity. In practice, therefore, they do not seem to have promoted the democracy. Nevertheless the Helizea did umpire all disputes public or private, 3 for most of the laws were obscurely and ambignously worded; and parties failing to gain satisfaction from the laws always desired the jurors to settle the matter for them. ${ }^{4}$ In consideration of the weak position of the lower classes Solon also made a law which "gave every citizen the privilege of entering suit in behalf of one who had suffered wrong. If a man was assaulted, and suffered violence or injury, it was the privilege of any one who had the ability and the inclination, to indict the wrong-doer and prosecute him." 5

Remaining information on the constitution is of a fragmentary nature. Officials in addition to the Archons were the Treasurers and Vendors who were chosen from the three unper classes in proportion to the amount of their assessments; the Paymasters were

1. Arist. Polit. II, ix, 2

2. Elected by lot; see Arist. Polit. II, ix, 3

3. Arist. Ath. Const. IX, 2

4. Plut, Solon, XVIII, 3

5. Ibid. XVIII, 5 
chosen in a like manner. The Treasurers were elected by lot

from the Pentacosiomedimni exclusively. ${ }^{2}$

With the Constitution completed and other laws supporting it,

the work was written up on boards and placed in the royal colonnade

where all could see them. All officers wore to obey and observe

the laws, 3 and Solon relinguished his power with the understanding

that the laws were to remain unaltered for a period of ten years. 4

Development of the Archonship. During the entire period of the

aristocratio domination of the constitution the office of Archon

Eponymus was the center of attraction because of the powerful

influence which went with such authority. Since each of the

powerful families wished to attain the administrative supervision

as much as possible, factional strife was a frequent outcome of

rivalry for the position. 5

1. Arist. Ath. Const. VII, 2-3

2. Ibid. VIII, 1; the laws of heiresses were an interesting example of Solon's conception of a man's duty toward his wife. The ruling was that no man could inerely marry for an estate, but must carry on a husband's duties toward her. Should the man nrove faithless the heiress was entitled to a divoree, but if she should remarry she was instructed to choose her new spouse from the family and lineage of her forner husband. This provision was probably a means of preventing strife among families over the question of wealth now that social ratings were dependent on that item. See Plut. Solon, XX, 2-3

3. Plut. Solon, XXV, 1; see also Arist. Ath. Const. VII, 1-2

4. Herodotus, I, 29. Aristotle and Plutarch say one hundred years, but Herodotus ascribes Solon's ten year journey to his desire to avoid chances himself which they could not make, It is also significant that no change took rilace in the covernment (save once when no Archon was elected) until after the ten year period.

5. Arist. Ath. Const. XIII, 2 
From the time of its institution the Archonship had been a device of the aristocracy, and in its oricin was aimed at the abolition of monarchy. That the device was a success is witnessed by the tradition that the family of the Medontids abandoned their royal prerogatives for the privilege of exclusive possession of the office. ${ }^{1}$ With the old royal family reduced to a position of equality with themselves, the Eupatrids as their next step opened the office to families other than that of the Medontids thus destroying the monopoly which had been the previous practice. 2 Making certain stipulations concerning the wealth of an Archon the nobles still further undermined the old privileges of royal birth.

With the opening of the office to all wealthy members of the Eupatrids, it renained to secure some means of preventing the dominance of one family for too lone a period. The result was a reduction of the term of office from life to ten vears, and in a short time to the final term of one year without the privilege of reelection. 3 By B.C. 650 the one year plan was firmly rooted.

But a new problem had arisen; the Archonship had become too powerful. The institution of the Thesmothetae met the difficulty by breaking up the power of the office and distributing most of the judiciel duties on the six new officials thus created. Although considered assistants to the three major Archons, the

1. Arist. Ath. Const. III, 3

2. Ibid.

3. Ibid. III, 4 
Thesnothetae were beyond their reach in certain matters. Through creation of the Junior Archons the Eupatrids not only decentralized the great power of the Archonship, but also provided additional posts of honor and power for themselves. This meant that each of the great families could under normal circumstances hold one of the offices frequently, and the device of the lot secured the offices from favoritism. ${ }^{1}$ With the election taken from the supervision of the Areopagus by Solon, the Archonship was now fair game for anyone with the qualifications.

Even these devices failed to reduce the prominence of the Archon Eponymus. Since he had general contral of the administration, his powers were considerable, and as time went on he constantly found his strength being augmented by the acquisition of new duties. ${ }^{2}$ Thus the Archon Eponymus becane more powerful despite his loss of legislative authority. With this increase of power the citizens felt it necessary to introduce some type of check, and by the time of Draco the principle of requiring an andit of accounts before permitting retirement into membership of the Areopagus had come into being. 3 Even in Solon's day, the Archon Eponyrns was aveilable only to those persons of at least moderate wealth, but the wealthy persons were also those of the powerful Eupatrids. Thus powerful families such as the Medontids and the Alcmaeonids

1. Aristotle, Ath. Const. III, 5

2. In this respect the growth of the administrative power of the President of the United States is a parallel.

3. Arist. Ath. Const. IV, 2 
found their position enhanced, and a union of such strength with the Archonship inevitably made the latter more and more powerful. Under such circumstances it was certain that factional strife would break out with the Arohonship as the goal should Solon's reforms fail to quiet the rival families. Public Reaction against Solon's Constitution. Having completed his laws, Solon went on a ten-year trip which took him far from Athens in order that his constitution might stand on its own merits. He did this because people kept coming to him worrying him about his laws. They were constantly criticizing certein perts and asking him questions about others. Since some were still pressing him on the point of tyranny, he doubtless felt that a continual explanation and amplification of the laws by himself might lead him into the tyranny he dreaded. ${ }^{I}$ Another reason for his decision was the disfavor of the factions each of which was disappointed at the settlement which they felt had not gone far enourh. Since he did not choose to take sides, or to oreate for himself a tyrenny, solon steadfastly refused to make changes in the laws. 2 Making his ownership of a vessel an excuse for foreign travel, Solon applied to the Areopagus for a leave of absence, ${ }^{3}$ announcing his intention to trade and see the world for a period of ten years. ${ }^{4}$ Secure in the knowledge that the Athenians would be vnable to repeal the laws for the ten year

1. Arist. Ath. Const. XI, I

2. Ibid. XI, 2

3. Plut. Solon, XXV, 5

4. Hdt. I, 29 
period because of the oaths they had taken, he set out on his journeys and left his laws to take care of themselves. 1

Dissatisfaction with the laws now blazed forth, and the old parties of the Hill, Shore, and Flain were reorganized. Among the Solonian laws was a general amnesty granting full rights and citizenship to all persons exiled before formation of the new constitution except those disfranchised on charges of murder, homicide, or seeking to establish a tyranny. 2 This decree was a signal for the return to Athens of the Alcmeoonids under the leadership of Megaoles. During their exile the family had established friendly relations with Croesus of Lydia, and had gained through these contacts a sizeable fortune. 3 Always a nowerful graup, the Alcmaeonids returned to Athens even more powerful than when they had left thanks to Solon's "timocratic" class system. Doubtless rival nobles resented their retum and began to revive the old charge of the blood taint. ${ }^{4}$

Failing to gain support from the Eupatrids, the Alcmaeonids turned their attention to the Demiurgi and soon organized them against the nobles. In choosing the Demiurgi as the basis of opposition to the Eupatrids it is likely that the Al cmaeonids were influenced by new citizenship which had been gained by that group. Hiore prosperous than the peasants and yet barred from

1. Hdt. I, 29

2. Plut. Solon, XIX, 3

3. Hdt. VI, 125

4. See pages $14-15$ 
membership in the nobility, the merohants held an in-between position. Since the Alcmaeonids were repudiated by the Eupatrids and had a natural aversion toward the cormons, they found themselves in a position similar to that of the Demiurgi; and their leadership of the Shore faction was probably a consequence of this similarity. Within a short time a feud developed between the Shore faction under Megacles and the Plain faction under the leadership of Lycurgus, son of Aristolaides. A general state of disorder now ensued with sone wrangling over the cancellation of debts because the laws had made them poor and others because of the groat change that had taken place. Others among the nobility contributed to the general dissention through their mutual rivalries. "The Shore faction consisting chiefly of the merchants favored a compromise constitution, and under the leadership of Megacles were inclined to support the Solonian arrangement. The Plain, an exclusive faction of the nobles, desired an oligerchy and were lod by Lycurgus. 3 Despite these internal storms the city maintained peace between the groups, but the fifth year after the departure of Solon found the party strife so great that no Archon was appointed.

Apparently some compromise must have been reached for the four succeding years found the general elections taking place as before. At this point a new power appeared on the scene in the person of Peisistratus, a third cousin of Solon. Aiming at eventual tyranny

1. Hdt. I, 59

2. Arist. Ath. Const. XIII, 3

3. Ibid. XIII, 4

4. Ibid. XIII, I

5. Plut. Solon, I 
and willing to bide his time, Peisistratus carefully laid his plans for gaining the sovereign power and decided thet his best chnce lay with those opposed to the Eupatrids. Acting on this conclusion he organized a faction directed against the Plain ${ }^{1}$ realizing that anyone who attacked the rich could count on the support of the common people or the nerchants and gain their confidence. 2 as a result he was appointed head of the Hill faction which was made up of diverse groups. Included were the Thetes -- bitter enemies of the rich, those nobles who had lost their wealth as a result of the debt cancellation, and those citizens not of pure descent and therefore fearful of losing their citizenship should an oligarchy be formed. 3 It was believed by all in the city that the Hill faction aimed at democrecy.

Once again the factional strife flared forth and as had been the case five years previously the Archonship was suspended through inability to arrive at an election. 4 This failure to elect Archons is on indication of the dangerous state to which the city had come. Fearing to chenge the constitution because of the oaths they had taken and unwilling to see their rivals installed in power, only one recourse remained -- the negative action of refraining from an election.

1. Arist. Polit. V, i, 5

2. Ibid.

3. Arist. Ath. Const. XIII, 5; the latter group was probably in large part composed of the craftsmen who had been attracted to the city by Solon's offer of citizenship.

4. Arist. Ath. Const. XIII, I 
Although the laws were still being observed, all factions were expecting a revolution; and each group wished to have a different form of government not for the bonefit of all but for the sole purpose of gaining entire mastery of all opponents. It was during such a period of tension that Solon returned to Athens. 1 Though he resumed his membership in the Areopagus, 2 the revered and honored man, thoroughly worn through his travels, was unable to take part in public affairs as had been his wont. 3 Nevertheless he did confer privately with the leaders of the opposing factions endeavoring to reconcile their differences and restore hermony to the oity. Of all the leaders Peisistratus appeared to heed his advice more than others probably in an effort to add to his popularity. 4

Another five years passed, and one Damasias gained the Archonship (apparently in a legal menner) holding the office for two years and two months. This was a definite attempt at tyranny, and Damasias held the office until he was driven out by force. After his deposition the factions arrived at a compromise by which ten Archons were elected distributing five to the Eupetrids, three to the Ceorgi, and two to the Demiurgi. 5 These men served in the vear following the

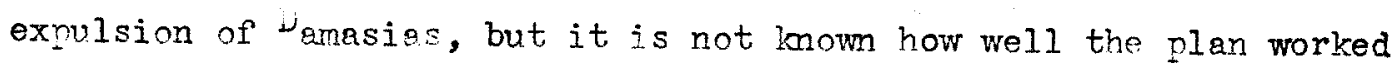
or how long it was retained.

1. Plut, Solon, XXIX, 1

2. Plut. Mor. $790 \mathrm{C}$

3. Solon was 56 years old at this time.

4. Plut. Solon, XXIX, 2

5. Arist. Ath. Const. XIII, 2 
Little is known of the happenings in the years that followed, but it is certain that Peisistratus was not idle. When the Athenians went to war against Megara (B. C. 570-565) he played a prominent part, and won quite a reputation for hinself as commander of the army - Under his leadership the Athenians took Nisaea, and Peisistratus through the performance of other great exploits emerged from the war as a great popular hero.

Peisistratus now judged the time was ripe to attempt a seizure of the city. Of an illustrious family, seemingly in sympathy with Solon's ideas, and well e stablished es a leader of the Hill, he felt that now wes the time to capitalize on his military glory. As the foremost nopular leader, it is probable that he functioned principally through the Ecclesia for we find him utting his plan into execution through that body where he had used the methods of a demagogue. 2

One day in B. C. 560 Peisistratus wounded himself and his mules and drove his carriage into the market place with the tale that he had been set upon by his enemies (presumably of the Plain or shore). Representing that he would have been slain had he not escaped, Peisistratus arnealed to the Ecolesia for a merd in order that his life be not further endangersd. 3 He requested a guard of four hundred young men. 4 Solon saw through this subterfuge despite his

1. Hdt. I, 59

2. Arist. Polit. V, viii, 4

3. Hdt. I, $\frac{59}{59}$

4. Diog. Laert. Solon, I, 66 
age, and formally opposed the oranting of such a request; he flatly accused Peisistratus of aiming ot a tyranny and rebuked those too 1

cowardly to do anything about it. When he saw, however, that the poor were overwhelmingly in favor of protecting the life of their leader while the rich were fearfully avoiding any conflict with him, Solon left the meeting and wat home. Nith his withdrawal any possible opposition was silenced, and the Ecclesia passed the desired decree permitting Peisistratus to chose any amount of club-bearers that he found needful. 2

Shortly thereafter Peisistratus rose up against the city and seized the Acropolis. Although this was a bold stroke he received little opposition for he had previously as hea of the people under unknown circumstancs driven out many of the more powerful families as partisans of oligarchy. 3 Seeing the hopelessness of their position possibly through loss of the leadership of the Shore, Wegacles and the rest of the Alomaenids immediately fled from the city since opposition was useless. 4 solon, though now without a narty, sourht to oppose the movenent and stood in the market-nlace exhorting the citizens to preserve their liberty. No one had the courare to sunport him, however, and he returned to his house. 5 Al thoum now

1. Arist. Ath. Const. XIT, 2

2. Plut. Solon, XXX, 3

3. Isoc. Panathenaicus, 148; Lyourgus was undoubtedly included in this group. Peisistratus may have collaborated with iegacles to achieve their expulsion.

4. Plut. Solon, XXX, 4

5. Ibid. 
seventy-nine years old, Solon still retained his spirit and continued to call upon the citizens to redeem their liberty and resist the tyranny, but in vain. 1

Peisistratus, now master of the situation, and realizing the harmlessness of the old man, endeavored to win him over by honoring him, showing him kindness, and inviting him to his palace. 2 In setting forth his position the tyrant argued that he had merely resumed the old privileges such as had been enjoyed in former times by Codrus, his ancestor. Aside from that (he said), no other changes had been made, for the Athenians were still managing their affairs according to the laws which Solon had established. ${ }^{3} \mathrm{~F}_{e}$ further argued that the people were better governed under his loadership because he allowed no one to overstep his rights, and yet took to hinself no "undue share of reputation and honor." 4 The net result was the winning of Solon's friendship so that the old law-giver actually acted as his counsellor and anroved of many of his acts. 5 On his ow part Peisistratus retained most of Solon's laws and subjected himself and his followers to their provisions. On one occasion he even submitted to trial before the Areopagus on a murder charge, but was acruitted when his acuser through fright failed to appear.

1. Plut. Mor. 795

2. Plut. Solon, XXXI, I

3. Diog. Laert. Feisistratus to Solon, I, 53

4. Ibid.

5. PIut. Solon, XXXI, I

6. Plut. Solon, XOXI, 2 
Solon survived Peisistratus's accession to the tyranny by only one year dying in B. C. 559 at the age of eichty years, but the tyranny was not destined to have smooth sailing. Megacles and Lycurgus as exiles reconciled their differences, and the year B. C. 556 sew the Eupatrids, together with the Alcmaeonids, banishing Peisistratus from the city and taking control for themselves. 2 This development could not have been entirely unforeseen, for much unrest had taken place in the city among the nobility. As a consequence of this Peisistratus was probably seeking some means of diverting attention from himself as well as providing a place of refuge should he be forced to flee from the city. A war in the thersonesus having developed between the native Dolonoi and their northern neighbors (Lampsacenians), the former applied to the Athenians for aid, requesting a leader who could win for them their independence. 3 This fitted very well into Peisistratus's scheme, and he devised the plen of sending a party of eitizens to the chersonesus as a colony. The condition within Athens can be seen to have been tense and uncertain in the desire of a great many persons to take part in the migration. Among those nersons desiring to take part in the expedition was Miltiades, son of cypselus, a powerful man of illustrius descent. Although of mixed Aeacian and Aeoinitan extraction, his family had been established in Athens for many generations. Impatient of the

1. Diog. Laert. Solon, I, 62

2. Hdt. I, 60

3. Ibid. VI, 34

4. Cornelius Nepos, Miltiades, I, 2 
rule of Peisistratus and anxious to ret away from it, he welcomed the invitation to lead on his ow responsibility and rerhaps gain a more desirable situation. ${ }^{1}$ Having been assured of the assent of the rods and accompanied by a hand-picked band, he set sail with a floet for the Chersonesus with the full approval of Peisistratus."

When he arrived on the scene he immediately engaged with the Lempsacenians, but had the misfortune to be waylaid and captured by theil. Fortunately Miltiades har a strong friendship with croesus, the powerful Lydian king, who threatened his captors with reprisals should they harm him or retain him in captivity. In deference to Croesus's wishes, Miltiades was set free and soon established his own authority. 3 As a token of their gratitude the inhabitants of the region made him in effect a despot al though he had no official title. Despite the strength of his position Miltiades remained subject to the will of Athens, and retained permanent alxthority in the Chersonese peninsula despite the turmoil that was raging in his home city. ${ }^{4}$ As time went on, he even found it possible to take control of the neighboring island of Lemnos:

Meanwhile affairs in Athens took a turn in favor of Peisistratus. With the denocratic faction ripped to pieces as a result of the expulsion of their leader, the Eunatrids and the Demiurgi took control of affeirs. Soon they were at each other's throats probably as a

1. Hdt. VI, 35

2. Nepos, Milt. I, 4

3. Hdt. VI, 37

4. Nepos, Milt. II, 3

5. Ibid. II, 5 
result of their differing opinion on the subject of an oligarchy, and Megacles found things going ggainst him. Turning to his erstwhile enemy, Peisistratus, Megacles offered the hand of his daughter in marriage as a condition of supporting his bid for the sovereign power. Peisistratus accepted the offer, and after creating a rumor that the gods had bidden his return, was warmly recelved by the populace. But Peisistratus was fated to enjoy his second installment of tyranny for an even shorter time than before, for he soon fell out with but he had no wish that his newly found wife should bear him children because he dreaded the effect of being connected with the famous Alcmaeonid blood curse. ${ }^{2}$ Furthermore he had other children by a previous marriago and had no desire to causo a dynastic quarrel among his heirs. He, therefore, refused to grant to his wife the customary marital relations, and Megacles feeling greatly dishonored patched up his quarrel with the oligarchic faction. Facing an ugly situation Peisistratus voluntarily quitted the country and set out for Luboea where he and his sons held counsel. 3

Deciding to regain the sovereignty they began to collect money and line up allies for their purpose. The friendly relations which Peisistratus had maintained with many of the Greek states now began to bear fruit. All cities wich were under obligation ${ }^{4}$ begen to

1. Hdt. I, 60

2. See pp. 14-15

3. Hdt. I, 61

4. Exact nature of obligations unknown; possibly treaty arrangement or sympathetic tyrannies which might have received similar help in the past. 
contribute great sums, and the strong city of Thebes geve more than any other. Finally after ten years of preparation they were ready to strike. Supplied with mercenaries from Argos and creatly aided in money and men by Lygdamis of Naxos together with all other supplies which ha been gained, everything was ready for their retum.

The expedition set out from Eretria and landed at ingrathon where they were joined by partisans from the neighboring villages and even from Athens itself. The loyal citizens, now realizing their peril, set out to attack him, but in vain. ${ }^{2}$ The adherents of Peisistratus easily put the Athenians to flight, and it is probable that many of these were only engaring in the battle for a sham since Herodotus states thet many of these upon encouragement from Peisistratus's sons went tho their homes thus destroying the morale of the others. 3

Peisistratus was now supreme and took measures to assure his continued leadership. Establishing a strong armed guard and collecting revenue from the river Strymon as well as from Athens, he made certain of their loyalty. Seizing the sons of the noble Athenians who remained within the city, he sent them to "ixos where they remained as hostages under the guard of Lygdamis whom he had previously appointed covernor. Other powerful families such as the Alcmaeonids, and even Jimon brother of ililtiades, were exiled

1. Hdt. I, 61

2. Ibid. I, 62

3. Ibid. I, 63 
and forbidden to return to the city. By such means Peisistratus made certain of his continued domination of the eity. 1 Feeling that his nosition was now secure, he proceeded to set the city in order.

Once he had established himself, Peisistratus conducted himself with rare wisdom and geined a reputation as a ruler second to none. In later years it was said that he and his son, Hiprias, conducted the government in such a manner that they were wiser in warfare and statroraft than Periander, famous as one of the seven wise men, and further that they were more humane than he.?

Peisistratus greatly fevored the thorough cultivation of the land for he wished to keep the people satisfied. Having ridden to power through their support he realized the necessity of providing for their needs as a means of retaining popular leadership. $\mathrm{H}_{e}$ was therefore kind and lenient with all offenders goninst the law, and advenced money to the poor in order that they might develon their farming activities. His purpose was to prevent their stonging in the city and interesting themselves in public business; thus he hoped to reduce the Ecclesia to a position of impotence through disuse. 3 Furthermore the added industr. would increase his revenue which amounted to one-tenth of the produce of the land. 4 As a logicel sequence of this desire to keep the people scattered on their

1. Hdt. I, 64

2. Fausanias, Description of Greece, I, xxiii, I

3. Arist. Ath. Const. XII, 2-3

4. Ibid. XVI, 4 . 
farms, he organized the local justices who settled disputes on the spot and even took to the circuit himself in order that the men might not be required to neglect their work by a journey to the city. I That this encouragement of the farm industry bore fmit is witnessed by the fact that Hippies and Hipparchus reduced the produce tex from one-tenth to one-twentieth of the land income. 2

For the most pert the government of the Peisistratids was agreeable to al1. They cltivated all of the arts and encouraged the intellectual life of Athens. A public works progrem adomed the city and mene the citizens conscious of the strength of their comminity - Religious festivals were ancouraged, and the tyrants were actively engaged in their supervision. 3 In their legal actions they were coreful to remain for the most part subservient to the laws thu concealine the operation of their tyranny so far as possible. 4 Indeed, the only serious elteration in the city laws releted to the Archonship which they generolly har some nember of the femily occupy. 5

The foreign nolicy of the Peisistratids was for the most nart one of friendliness for neighboring states. Except for the war with Hytilene in B. C. 535 when Sigeum was receptured, no serious diffi-

1. Arist. Ath. Const. XVI, 5

2. Thuc. VI, 55

3. Ibid. VI, 57

4. Arist. Polit. V, ix, 21

5. Cf. note 2. Peisistratus probably retained for himself the position of King-Archon which must have been over and above the repular Archonshin; or his office mi tht heve been a tenth Archonship inspired by an earlier arrangement. See pege. 47. 
culties developed with other cities ir Hellas. Wacedonia and Thessaly were definitely allies, ${ }^{l}$ and Sparta and Thebes were outstanding in their support of the regime. The tyrants had thus lifted thens to a powerful position in the Aegean region. Sigeum was under the governorship of Hegesistratus, a bastard son of Peisistratus, and desvite disorders in the region remained a stronghold nf the tyrenny. 2 Nexos had been subdued and served as a station for the guarding of hostages. 3 The chersonesus and Lemnos under Hiltiades secured a strong nosition in the northern Aegean. 4

An evidence of the leniency of the tyrents con be seen in their relations with the family of Miltiades; and yet a vindictive strain can also be detected. Cimon the brother of Miltiades had been exiled when Peisistratus came to final nower, 5 but built up a reputation for himself as a charioteer winning the 0lympic prize on three occasions. At his second victory he seems to have made some sort of deal with Peisistratus who desired to attain such honor for himself, for we find him relinquishing his victory to the tyrant in return for a restoration of citizenship. On his return to Athens Cimon took with him his younger son Miltiades (named for his uncle the mler of Chersonesus) but left Stesagoras, the eldest, with his brother in the Chersonesus. As a

1. Hdt. V, 94

2. Ibid.

3. Ibid. V, 64

4. $\sqrt{\text { Npos, }}$ Milt. II, 3,5

5. See pp. $\overline{54-55}$

6. Hdt. VI, 103 
citizen of Athens he added to the honor of his oity by winning his third championship at Olympia. Shortly thereafter Peisistratus died at an advanced age and Cimon for reasons unlnown was assassinated at the orders of Hippias and Hipparchus, possibly through fear of his great popularity. ${ }^{l}$ Not mach later his brother Miltiades died childless leaving his government and possossions to Stesagaras.

When Stesagoras met with death at the hands of an enemy in Thrace the country was left wi thout a leader. ${ }^{2}$ Hippias in seeking a new governor for the colony immediately chose youn Miltiades, son of cimon, to succed his brother since he had already proved hirisolf useful to the aministration of eity affairs. ${ }^{3}$ Setting out in a trireme Miltiades soon arrived in the colony, by a strategem seized all of the leading men in the surrounding cities as hostages, and set himself up as a tyrent. Froviding himself with a bodyguard of five-hundred men he married the daughter of the king of Thrace and with this alliance ruled the northern region for a time without opposition. 4

The Constitution under Peisistratus. Although he held the government by force, Peisistratus maneged to carry on his administration without seriously interfering with the Solonian constitution. 5 The source of

1. Hdt. VI, 103

2. Ibid. VI, 39

3. Ibid. Possibly a means of removine a potential menace to the tyranny in consequence of the aseassination of his father.

4. Hat. VI, 39

5. Hdt. I, 59; se日 al so thuc. VI, 55; Plut. Solon, XXXI, 1-2; Arist. Ath. Const. XVI, 8 
his power lay in a by-passing of Solon's laws concerning the Archonship. As he explained it Peisistratus took for himself all of the power of the life-Archon of the pre-Solonian constitution and was content to hold the extensive administrative powers of that official. It was as chief adninistrator that he was enabled to assess and collect taxes, and as life-Archon he was in a position to dominate the council of the Areopagus over which he presided. That body was all the more subservient to his will since it was packed by ex-Arcions of his owm selection or in sympathy with him drawn for the nost part from his own family.

He loubtless had administrative control of the courts as is seen both in the old time power of the life-Archon and in his appointment of local justices. ${ }^{3}$ Furthermore he was nopular with the Hill, and as orgenizer of thet numerous faction was able to dominate the Ecclesia. Further than this he did not go. The actul legisletive end judicial powers of the Areopegus remained untouched, so mich so that he hinself submitted to the serious charge of homicide and placed himself in their hands. The tyranny functioned, not by destroying the laws, but by obliterating a portion of them through disuse. ${ }^{6}$ Peisistratus wished to lead and carry on the administration. other than that he had no ambition. "hat he was fair and somewhat

1. Diog. Laert. Peis. to Sol. I, 53

2. Thuc. VI, 55

3. There were thirty of these. See Arist. Ath. Const. XXVI, 3

4. Arist. Ath. Const. XXVIII, 2

5. Ibid. XVI, 8; see page 50

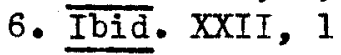


popular is seen in later references to his regime as "the golden age." ${ }^{1}$. His son Hippias continued along the same lines for the greater portion of his career as tyrant, ${ }^{2}$ and had not the asassination of his brother occurred would doubtless have continued so to the end of his life.

Solon's Constitution under Peisistratid lianagement. The chief administrative officials were the Archons of which there were nine. These officers were all restricted to the two upper classes as determined by the produce of wealth in a one-year period. The Archon Eponymus was restricted to the Pentacosiomedimni, however. Each tribe made a preliminary selection of candidates, and from this rroup the people crose nine by vote. 3 once elected the Archons remained accountable to the people, and each was bound by an oath to dedicate a gold statue of a man should the laws be transgressed. 4 There were also certain fines for failure to punish offenders of the laws.

The nine Archons were divided into two groups -- the major Archons (Archon Eponymus, Basileus, 5 Polemarch) and the minor Archons (Thesmothetae) of which each major Archon had two as assistants. All of the Archons came together in the Legislators court, and each had an established court of his own. The Archon

1. Arist. Ath. Const. XVI, 7

2. Paus. I, xxiii, I

3. Arist. Ath. Const. XXII, 5

4. This part of the law must have been ignored under Peisistratus.

5. Major in consideration of the dignity attached to the of ifice. 
Eponymus was most powerful and carried out the chief administrative functions which included presiding over the Areopagus. 1 The Basileus was principally concerned with ancestral rites and had judicial duties of a religious nature including the power to pronounce curses. ${ }^{2}$ The. Polemarch wes war leader and held all powers connected with the administration of military affairs. The Thesmothetae were legislators and as such publicly recorded the ordinances, and preserved them for the trial of litigents. They also had power to give final judgments in lawsuits. Among them these nine men performed most of the public functions. Wany of these duties, however, were probably under direct supervision of the tyranny during the rogime of Peisistratus and his sons, and perhaps become a legal fiction.

The Areoperus was the center of the Solonian system. As guardian of the laws it had the duty of watching public activities and punishing serious offenders ggainst the Constitution. The Areopagus also supervised public morals including the right to try cases of homicide. 3 Set aside as the one body of experienced men each of whom as ex-Archons had served in the administration of the city, it was certainly composed of the most influential and nowerful men in the city. Since the Archonship was the entrence to the Areopagus many of the struggles over the magistracies mav be interpreted as an effort not to gain the Archonship for a one year neriod but to secure

1. Under the tyranny this nower was probably exercised by the Basileus

2. The powers of the Basileus were greatly expanded under Peisistretus and his sons, because the old king-Archon is the identical officer.

3. See page 35 
domination of the Areoparus which held the veto power over most of the functions of state. Even the Heliaea was overshadowed through failure to function as popular bodies tue to the inability of the Thetes to serve remlarly.

The Areopagus was the most dimnified of all the councils and consisted exclusively of ex-Archons who retained their nembership for life. Although they could he removed under certain conditions no definite restrictions are known except thet a member was required to make arplication for leave of absence thus indicating that regularity of attendence was probably one of tho requirements for continued membership. Any breach of the law incurring loss of citizenship was probably another cause of removal.

The chief duties of the Areopagus related to its position of supervisor of the pablic morals and the older power of suardian of the laws. In the latter capacity the Areopagus kept a watch on the most important aftairs of state, and the execoise of that power carried their comizance to most public activities. The sreopamites maintained a definite check on the maristrates and held them to the laws. 1 Anyone who offended arainst the comstitution was subject to correction, and those who attempted to overthrow the Constitution could be tried by the treopagus. 2

1. Probably not applied to the Basileus under the tyranny if Peisistratus utilized the office as king-Archon.

2. Another rood reason for the packing of that body by peisistratus 
The Areopagus had an important function as a trial body. In addition to cases of revolution the Council had exclusive charge of murder cases, and served as a court of anpeal against the magistrates. 1 Its moral supervision included trial of cases of sacrilege and investigation of cases of idleness with power to provide proper punishment therefor. This was a powerful weapon directed by the tyrants toward the clearing of Athens of those nersons who had no definite business in the city thus discouraging too much participation in the deliberative bodies. A further privilege of the body consisted of the right to use the public monies without a declaration of the reasons for such use. ${ }^{2}$ Although we have no details of its organization, the Areopagus was said to have excelled all of the other councils in its conduct of affairs. Its power was finel, admitting of no aneal from its decisions. 3

The Council of Four Wndred was created as a check on the Eoclesia. Tt consisted of four hundred members of which one hundred were chosen by lot from each tribe from the three yper classes. The lots were cast by oll citizens thirty vears old end over. Membership was limited to one year, and no nerson could be reelected until the entire list of eligibles had been exposed to the lot. Then it was possible to be reelected, but no one could serve on the council more than two years in his life.

1. The appeal power wes probably limited by the tyrants 2. A refuge for any finencial measures of the tyrants

3. No wonder Peisistratus took care that members of the family held the Archonship. A controlled Areopagus was vital. 
The principal work of the Council consisted of deliberating on public matters before they reached the Ecclesia. Without action by the Council, it was impossible for a natter to come before the popular body. Additional powers which were gained the expense of the Areopagus was the sovereign privilege to pass sentences of fine, imprisonment, and death; ${ }^{1}$ also the sovereign power to reject disqualified officers. As was tme of the Areopagrs, the Council expected the members to attend remlarly, and failure to attend meotings resulted in a fine. As a means of reducing the power of the Ecclesia, the Council probably functioned as a committee for that body.

of the Ecclesia, little is known. The membership included all the citizen-body of Athens which presumably put the Thetes in a majority, thus necessitating in Solon's eyes a check upon their ambition through creation of the Souncil of Four Hundred. It was clearl in existence in Draco's time though apparentl:r not open to the lower classes. It probably originated as a concession to the comon people who were otherwise without representation. The Ecclesia anparently had some power for providing for the safety of individuals as exemplified in Peisistratus's ampar to it for a bodrouard. It is possible that Solon was responsible for the induction of the lower class into the Ecclesia since he is credited with creating the body, 2 and also with creating the early stages of the democracy. This he probably achieved in his position as leader of the people.

1. Probably restricted under the tyranny

2. Solon may have assisted Draco in the latter's reforms. See page 17 
The Heliaea was another democratic element of the constitution and was considered by the Greeks to be the source of the people's power. All classes were represented, and every citizen had the right of appeal to the courts. The jurymen were elected by lot, and trials were held before a jury of three hundred. The Heliaea umpired all disputes public or private, and a third person could institute action should one person suffer injury at the hand of another. In all probability the Heliaea of Solon was an expansion of the old court of the nobles which existed in earlier times.

Others who were chosen by the citizens were the Generals. These officers were chosen from the three upper classes, were required to ow property worth not less than one hundred minae, and were required to have legitimate sons over ten years of age.

All citizens were numbered on the rolls who provided themselves with arns. Those thirty years of age and over could cast lots for offices. Although naturalization was rare, citizenship could be gained by permanent exiles from other states or by artisans moving to Athens with their families. Citizenship could be lost through conviction of murder, homicide, or tyrenny, or by a person failing to take sides should a factional stmagele arise.

So far as can be determined this was the constitutional situation when the year B. C. 510 arrived. Wuch of it in the hands of the tyrants had come into a state of suspended animation, but it still had sufficient hold on the citizen body to serve as a jasis for operation until a reform covld be made; and that reform itself was strongly built on the Solonian model. 


$$
-
$$


PART III

THE CONSTITTTTON OF CIEISTHENES

The Fall of Hipnias and the Tyranny. In B. C. 527 Peisistratus died, and his sons Hippias and Hipparchus came to the tyrenny. ${ }^{1}$ of the two, Hipparchus was little concerned with the administration preferring to devote his efforts toward cultivation of the arts. ${ }^{2}$ Hippias cerried on the administration, 3 and under him the tyranny followed the same lines as under Peisistratus.

Indeed, generally their government was not grievous to the multitude, or in any way odious in practice; and these tyrants cultivated wisdom and virtue as much as any, and without exacting from the Athenians more than a twentieth of their income, splendidly adorned their city, and carried on their wars, and provided sacrifices for the temples. For the rest, the city was loft in full enjoyment of its existing laws, except that care was always taken to have the offices in the hands of some one of the family. Among those of them that held the yearly archonship at Athens was Pisistratus, son of the tyrant Hippias, and named after his grandfather, who dedicated during his term of office the altar to the twelve gods in the marketplace, and that of Apollo in the Pythian precinct. 4

That they could be forceful and occasionally ruthless in their dealings with the people can be seen in Hipparchus's exile of his

1. See prge 58

2. Herodotus, VII, 6

3. Thu cydides, I, 20

4. Ibid. VI, 55 
friend Onomacritus for tampering with the text of a classio ${ }^{1}$ and their assassination of Cimon who had been returned from exile by Peisistratus. 2

It is evident that the tyranny under the brothers was anything but secure although it was unusually strong as tyrannies go. Hippias, accustomed as he was to inspiring the citizens with deep respect, maintained his corps of mercenaries in order that he might be ready for any eventuality. 3 When Hivparchus was assassinated in. B. C. 514, Hippias in rage and grief changed his policy of tolerance and vented his spite on everyone. 4 The consequence was a despotism which overrode the laws and resembled the modern concept of the word tyranny. 5

Unrest now began to develop within the city and the exiles, under the leadership of the Almaeonids, began to organize an attempt to seize the city. Not blind to these movements, Hippias begen to cement alliances with Thessaly ${ }^{6}$ and Sparta, ${ }^{7}$ and it is likely that friendship with Persia was gained through the agency of Miltiades in Thrace. 8 The exiles now attempted to $t_{a}$ ke the city by force, but the tyranny repulsed their efforts. 9

1. Hdt, VII, 6

2. See pp. 57-58

3. Thuc. VI, 56

4. Hdt. V, 62

5. Ibid. $V, 55$

6. Ibid. V, 63

7. Ibid. $V, 90$

8. Cornelius Nepos, Miltiades, III, 2. Miltiades's friendship with the Peisistratids may have resulted from the free hand which he exercised in the chersonesus. It was probably a case of tyrant supporting tyrant as a self protective measure.

9. HAt. $V, \div 62$ 
Seeing that, unaided, they were unequal to the task before them, the exiles fortified Lipsydrium to the north of Paeonia and began to devise a plan to detach Sparta from her Peisistratid alliance. The Alcmaeonids using thoir wealth ${ }^{l}$ froely contracted for the building of the Delphic temple and gratified the priestess by erecting a building much more magnificent than had been agreed. 2 They next bribed the priestess to tell the spartans that no affair of theirs public or private could be successfully concluded until Athens had been set free. Impressed by this oft reiterated command the Lacedaemonians, deciding to abandon their friendship for the Peisistratids and obey the commands of the rods, sent an expedition against Athens by sea. 3 The Peisistratids had already gotten wind of the plot, however, and sent to Thessaly for help. When the

- Spartans arrived the Thessalian cavalry overwhelmed their forces, killed their general Anchimolius, and forced their retreat. ${ }^{4}$ Undismayed the Lacedremoniens organized another expedition larger than before, sent it by land against the Thessalians whom they dispersed, and joinine hands with the exiles and others from within the city set upon the tyrannical family and ctrove them within their fortifications. The Peisistratids were strongly garrisoned and would probably have been able to outlast their

1. Gained from croesus (see p. 44) and probably so safeguarded that it did not admit of confiscetion by an enemy.

2. Hdt. $V, 62$

3. Ibid. $V, 63$

4. $\overline{I b i a}$. 
enemies, but fate was against thom. The besiegers had the good fortune to take into captivity the young sons of the Peisistratids as they were being oarried out of the country, and the tyrants to regain possession of their children submitted to the terms of the revolting Athenians and departed from the whole of Attica within a period of five days. I Thus the tyranny came to an end. Cleisthenes's Struggile for Leadership. On the surrender of Hippias the victorious exiles returned to the city. Foremost among these was Cleisthenes, an Alomaeonid, who had been largely responsible for gaining the Spartan alliance through managing the affair of the Delphic temple and he now aspired to the leadership. 2 This was a logical desire since he and his family had been largely responsible for the Athenian faction which hed played an important part in the expulsion of the tyrants. 3 opposing him was Isagoras, son of Tisandrus, a man of the nobility ${ }^{4}$ but a friend of the tyrants. 5 The goal of each was apparently the Archonship, and both men turned to the Brotherhoods for support since the nower of those bodies was decisive where Eupatrid leadership was concerned. In the ensuing strucrle Isagoras emerged with the victory and Cleisthenes despite his wealth found his adherents of the Shore ${ }^{6}$ unable to match the strength of the opposition. Cleisthenes having been rejected by the nobility, possibly

1. Hidt. $V, 64-65$

2. Ibid. V, 66

3. Aristotle, The Athenian Constitution, XX, 3-4

4. Hat. V, 66

5. Arist. Ath. Const. $X X, 1$

6. It must be remembered that the Alcmaeonids were traditionally of that faction from the time of Solon. See pp. 44-45 
because of his blood taint, turned to the people and quickly became their leader. ${ }^{1}$ The nobles in retaliation elected Isaforas Archon, ${ }^{2}$ probebly using the devices of the Peisistretids in the furtherance of oligarchy. In turn cleisthenes offered to hand over the government to the common people. 3

It is stated "that the tyranny had obliterated the laws of solon by disuse, $" 14$ and it must have been especially tme of the a thority of administrative officials. With a subservient Archonship and an Areopagus in disrepute because of its Peisistratid flavor, Isagoras seems to have had difficulty with the aiministration, and Cleisthenes working through the people was able to best him. 5 The case seems to have been nobles versus the people; oligarchy versus democracy. Since the people could only function in the Heliaea and in the Ecclesia, it is cloar that the strugele took plece in one or the other. The Heliaea, however, does not seem to have been a very suitable medium since at the time it was probably only infrequently invoked. Furthermore the Heliaeais power was that of interpreting, not making, the laws and thus was a somewhat passive euthority. Under the conditions of the tire, the Ecclesia was the only logicel scene of the clash. In any event, the strugrie seems to have been a peaceful one with Cleisthenes winning the victory.

1. Arist. Ath. Const. XXVIII, 2

2. Ibid. XXX, I-2

3. Ibid. $\mathrm{XX}, 1$; Ferodotus $(V, 66)$ says that he "took the people into partneeship."

4. Arist. Ath. Const. XXII, I

5. Ibid. $X \bar{X}, 1-2$

6. A result of Peisistratus's system of local justices. See page 56 
We find him dividine the whole body of people into ten tribes, replacing the ancient form. ${ }^{1}$ The new tribal arrangement was designed to put on end to the eternal strife between the factions of the Hill, Shore, and Flain byr destroying the power of the Eupatrids, Georgi, and Demiurgi to operate as separate political groups.

With the Eupatrids definitely losing power and the Areopams apparently uninterested possibly through hope of recalling the Peisistratids, Isacoras recalled cleomenes of Snarta, his nersonal friend, on the religious pretext of cleansing Athens of the Alcmaeonid curse.2 Cleisthenes, however, realizing that the new tribel errangement would work to the advantage of the common people and the merchents, was confident of his strenth of leadership and retired from the city ${ }^{3}$ since he knew he was stronger than his rivel. ${ }^{4}$ cleomenes, in answer to Isagoras's request had demanded the banishment of cleisthenes and his family in answer to which the Almaeonid hac departed, but the Spartan wes not satisfied. Appearing at Athens with a small force he banished seven-hundred families designated by Isagoras as under the curse. 5 Next, he tried to put dow the Council and set up an oligarchy.

Under his plan Isaporas and three hundred of his friends were to exercise the sovereign power, ${ }^{7}$ and it is probable that Isagoras

1. Arist. Ath. Unst. XXI, 1-2

2. Ibid, $\mathrm{XX}, 2$

3. Hdt. V, 72

4. Ibi.. T, 69

5. Hd.t. $\mathrm{V}, 72$

6. Ibid.

7. Arist. Ath. Const. XX, 3 
was intending to make himself tyrant. With the memory of Hippias and his tyranny still fresh in their minds, the people were greatly opposed to tyranny in any form or anything that remotely resembled it. Furthermore the Areoparus was still in all probability stronoly composed of Peisistratid symnathizers who had some hopes of restoring the exiled tyrant; and a strong oligarohy would mean an end to their dream. The reaction was not surprising. The Areopagus resisted, the people swarmed into the city from all sides, and Cleomenes and Isagoras were forced to take refuge in the Acropolis with their followers. I After a siege of three days cleomenes gained a truce and departed for Sparta, taking Isagoras with him, but the others were put to death. Cleisthenes and the seven hundred families were then recalled. In anticipation of a return of the Spartans, the Athenians now sought out an alliance with Persia, and their envoys accepted the Persian condition of giving "earth and water." When they raturned, the envoys were strongly rehnled by the people for their actions. "With Isagoras exiled and the Eupatrids without leadership Cleisthenes was complete master of the city and proceeded with his program of reform. 3 The New Constitution. A powerful figure, respected for his warlike proclivities, Cleisthenes submitted himself to the laws and as head of the people proceeded with his reform of the Constitution, basing his work on the Solonian model. 4 An Al omseonid and extremely wealthy,

1. Arist. Ath. Const. XX, 3

2. Hdt. V, 72-74. The envoys acted in behalf of the Ecclesia

3. Arist. Ath. Const. XXVIII, 2

4. Arist. Politics, V, ix, 21 
he boasted of Cleisthenes of Sicyon as an ancestor, $I$ and retained. support of the Demiurgi as had his family before him. Aside from the Shore class he could count on the su port of the common people working throuch the Eicclesia or Assembly.

The tribal reorganization, which ha already been started, was the principal change instituted. By setting up ten tribes he is said to have enabled more to take part in the government since the old distinctions of heredity were apperently broken down. ${ }^{2}$ The commons hai been debarred from all rights, but the new tribal subdivisions established the commons to a position of equality. 3 Each tribe consisted of equal parts, one each of the Shore, Hill, and Plain which parts were called thirds or trittyes. These thirty trittyes were assigned to the ten tribes by lot, but in such a manner that each tribe received one each from the three factional areas. 4 The distribution of these areas wes left to the lot, and as a result the tribes were scettered over Attica. With territorial unity thus dismpted another blow was stmick at factione.lism. Each tribe was further divided into ten divisions called dernes, and each deme was theoretically oredited with a candidate for the Archonship. 5 The demes each had a president or head called the Demarch who supervised deme affairs taking the place of the former ship-comissioners (Naucrariae). 6

1. Hdt. VI, 131

2. Arist. Ath. Const. XXI, 2

3. Hdt. V, 69

4. Arist. Ath. Vonst. XXI, 4

5. Ibid. VIII, I

6. Ibid. XXI, 5; for the Naucrariae see page 31 
This new plan resulted in corbining the classes and destroying factionalism. The new tribes received as eponymus deities ten heroes selected by an oracle of the Pythien priestess ${ }^{l}$ and the demes were variously named some from their localities and others from their founders. This was a blow at encestral pride. Also many new citizens were created from the resident aliens who had been either foreigners or slaves, ${ }^{2}$ closely connected with members of the shore faction. Included was the confirmation of citizenship held by those not of pure descent. 3 These new elements were scettered throughout the demes in order that no distinction might occur which would lead to factionalism.

...he mede all the inhabitants in esch of the demes fellowdemesmen of one another, in order thet they might not call attention to the newly enfranchised citizens by addressing people by their fathers' names, but to designate people officially by their demes; owing to which Athenians in private life also use the names of their demes as sumames.4

The old clans, brotherhoods, and priesthoods were allowed to function on their ancestral plan as before, but the new tribal system effectively limited their political influence permanently. New tribes and new brotherhoods replaced the old units as governmental entities, and the celebration of private religious rites became transferred to the new small number of public celebrations connected with the new orranizations. In the words of Aristotle

A democrac of this kind will also find useful such institutions as were employed by cleisthenes of Athens when he wished to increase the power of the democracy... different tribes and brotherhoods must be created outnumbering the old ones, and the celebration of private

1. Arist. Ath. Const. XXI, 6

2. Arist. Polit. III, $i, 10$

3. Arist. Ath. Vonst. XIII, 5

4. Ibid. XXI, 4-5 
religious rites must be grouped together into a small number of public celebrations, and every device must be employed to make all the people as much as possible intermingled with one another, and to break up the previously existing roups of associates. 1

This method abolished the effectiveness of the Enpatrid brotherhoods which haci manipulated the old tribal units. ${ }^{2}$ Now, their mombership was scattered among the new tribes and their members outnumbered two to one in each tribe.

A direct result of this new tribal arrangement was the reorganization of the Council of Four Hundred. Originally based upon the tribe, cleisthenes decided to continue thet relation, and raised the membership to five hundred with fifty me bers chosen from each tribe. 3 Each member was required to take an oath of induction. 4 So far as its powers were concerned the new Council seems to have been identical with the old body. It still possessed sovereign power to reject officials-elect as disqualified, and it retained sovereign power to pass sentences of fine, imprisonment, and death. 5 cleisthenes, however, by his tribel redistribution, eutomatically broke the power of the nobles in the Council, 6 and one of the first acts of the now Council was the passing of a death sentence rainst the partisans of Isagoras. 7

1. Arist. Polit. VI, ij, 11

2. Arist. Ath.Const. XXI, 3

3. Ibid.

4. Ibid. XXII, 1-2; became effective five years later

5. Ibid. XIV, 1, 3

6. Perhaps he remembered his defeat by Isagoras at the hands of the Brotherhoods and was aiming at them.

7. Hdt. $V, 72-73$ 
The Archonship was not seriously affected by the reforms. Each tribe, as before, selected ten candidates by lot, from a preliminary list of five hundred chosen by rote by the demesmen. 1 The nine Archons were then elected from the one hundred candidates, tribe by tribe. During the reriod from the end of the tyranny until B. C. 487, the Archons were finally elected by vote. ${ }^{2}$ The powers of the Archons seem to have remained unchenged.

The Areopagus seems to have emerged from the reorganization with most of its previous powers. Membership still consisted of ex-Archons on a life basis, and the Council continued to hold the principal power in the state. Furthermore, it was able at times to command full support. of the people. 3 within a few yeers the body became more and more influential. We find that the hreopagus still exercised the power to arrange treaties, and that it also had the power to recall citizens expelled for various reasons. 4

Although little direct information is provided on the coclesia, much can be inferred. It seems that cleisthenes increased the power of thet body, and that the power conferred remained even though, as we shall see, it yielded somewhat to the Areopagus during the Porsian Wars. It has already been indicated thet the Ecelesia possessed the power to provide for the safety of an individuel. 5 Cleisthenes

1. Arist. Ath. Uonst. XXII, 5

2. Ibid.

3. Ibid. $\mathrm{XX}, 3$

4. Ibid. XX, 3-4

5. See pp. $48-49$ 
apparently expanded that previously unasserted power into the practice known as ostracism. Ihat he began the arrangement of the ten tribes during the Archonship of Isagoras ${ }^{1}$ who definitely opposed the reform is another indication of the Ecclesia's influence. The frot that Cleisthenes operated under the laws ${ }^{2}$ is also significent, for he must have depended upon means sanctioned by the Constitution i. e. implied powers or laws which had previously been ineffective.

The power of ostracism was en exemple of such legal adaptation of on old law to a new situation. Solon had found it necessary to provide some means of forcing the participation of all citizens in factional disputes as a meens of ensuring the expression of the will of the entire citizon bodr. The penalty of disfrenchisement for failure to narticipate was his solution. 3 similarl. cleisthenes instituted a srfety device. in the form of ostracism by which any person considered by the citizen-body to be dangerous to the democracy might be exiled for a ten-year period. ${ }^{4}$ The law onerated through a prelininary vote held in the council of Five Iundred 5 and in the Ecclesia. If an ostracism was found to be desirable, a proclamation was made, and on a set date the citizens wero invited to come to the Ecclesia and name by secret ballot the person he

1. Arist. Ath. Const. XXI, 1-2

2. Arist. Polit. V, ix, 21

3. See pare $\overline{33}$

4. Plutarah, Aristides, VII, 5

5. Arist. Ath. Const. XIIII, 5 
considered dengerous to the stete. If six thousand persons or nore participated, the votes were counted end the person named by a plurality of the participants was declared ostracised, and riven ten days in which to leave the oity. ${ }^{l}$ The device did not reflect dishonor or severance from the city's authority. Durine the exile a citizen was still nemitted to onjoy the incone from his pronerty, and was subject to recell by the oity for any reason it domed sufficient. 3

Some anthorities regard the prectice as a nolitical dovice aimed bir cleisthenes at tho smpathizers of the Peisistratids and others of oligarchical loanings, 4 and it wes certajnly used with that effect in its early employment. There is a strone probability, however, thet the ostracism ployed on importent part in the development of the Ecolesia's power. In the first place it was a device in line with popular sympathy since it was a reaction to suspicion "felt against the men in the positions of power becanse Peisistratus when leader of the peonle ond ceneral set himself up as a trrant;" 5 secondly, the ostracism was exercised by the people and undor its supervision (sinco the citizen-body was the Scclesia); finally, there is a probability that the threat of ostracism was an important foundation of theEcclesia's nower to effect the later great changes;

1. Plut. Arist. VII, 4-5

2. Ibid. VII, 5

3. Thuc. I, 135

4. Arist. Ath. Const. XXII, 4

5. Ibid. XXII, 3

6. Plut. Arist. VII, 4-5 
opponents of the democracy would fear to offer opposition since their immediate influence mint be completely obliterated by an application of the principle. At any rate, the importance of ostracism in forcing changes is a fact, since every vear which saw an increase in the power of the democracy also witnessed the ostracism of a nember of the opposition.

Election of the Generals was by tribes one from each tribe. Although the ten generals now represented the tribes, the Polemarch. still occupied his position of eminence and seems to have been more or less influential in the direction of the army at Marathon. 2 It may be that the fact that the Cenerals (Strategi) represented the tribes ${ }^{3}$ accounts for the later influence which they exerted in the governmen since they combined the features of direct responsibility to the people plus direct selection by vote instead of receiving office by the lot.

Concerning the Heliaea no evidence is available, and apparently the Solonian system went on without chan me.

Generally speaking, Cleisthenes's reforms do not seem to have had the demooratic effect that is comonly supnosed. As already indicated the constitution was strongly based on the preceding work of Solon. The lower classes were still excluded from the offices, and nong fo tho arictocratic devices were definitely changed.

1. Arist. Ath. Const. XXII, 3; but at a later date this process seems to have come nder the sunervision of the Douncil of Five Fundred. See Arist. Ath. Const. LXI, I

2. Cf. note 1; the institution of the ten renerals took plece in B. C. 501

3. It must be remembered, however, that the tribes were not territorial units since they were scattered all over Attica. 
Except for the reorganization of the tribes the aristocracy does not seem to have suffered iminediate hurt. The truth is that cleisthenes made changes that had great potential power, and that the growth of the democracy gradually came about through a slow process of converting the potential into actual power. It is also likely that tho Perisan Wars interfered with the functioning of Cleisthenes's reforms. By maintaining friendly relations with Sparta, it was possible for the aristocratic element working throuch the rroopagus to doninate the scene during a seventeen-year period. The struggle for supremecy during the period B. C. 487-475 seems to bear out this theory.

Furthermore the Constitution as it oneroted under cleisthenes's inmediate reforms did not conform to the Greek view of democracy. Ferodotus pictures the virtues of denocrey in the following words: ...the virtue of a multitude's mie lies first in its excellent name, which simifies equality before the law; and secondly, in that its acts are not the acts of the monarch. All offices are assigned by lot, and the holders are accountable for what they do therein; and the general assembly arbitrates on all counsels. 1

Accordine to this viow ithens was not yet a democrecr in fret since equality before the law had only been attained in theory, and the Ecclesia was not yet the veto power in the state save through the indirect method of ostracism.

1. Hdt. II, 80 
The Council of Five Hundred. An important source of governmental activity during the Cleisthenean period was probably the Council of Five Fundred. It was an adaptation of the old Council of Four Hundred. The origin of the ouncil is uncertain but it can be placed in the time of Draco. It is possible that the creation of the Ecclesia as a popular body had divorced it from its subordinate position under the Areopagus and that the Council was a means of. providinm the same checks on the Ecclesia's power as had been applied in the past by the Areopegites. It is interesting to note that from the beginning it was a means of semring dominance by the unper classes since the Thetes were never admitted to membership.

The property qualification remained the principle of membership until the time of Pericles and there is reason to believe that even then it was not repealed but merely ignored. 2

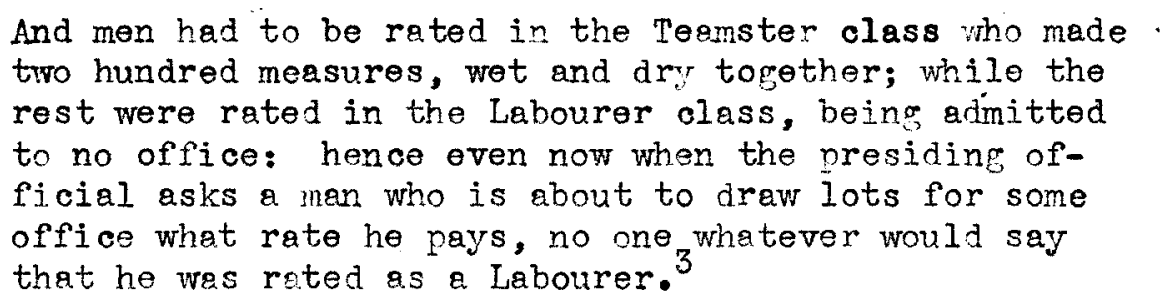

Under Solon the Council became a check on the Ecclesia for which it prepared the public business and without which preparation the popular body could take no action. ${ }^{4}$ A close relation with the tribal

1. Arist. Ath. Const. IV, 3

2. Ibid. VII, 4

3. Ibid.

4. FIut. Solon, XIX, 2 
system existed, and the selection of the Archons was reatly influenced thereby. ${ }^{l}$ We also find the council exercising the sovereign power to pass sentences of fine, immrisonment, and death thus rising to a relatively powerful osition in the state. 2

Under Peisistratus the Council must have been largely composed of hand-picked membership subject to his will, but cleisthenes restored the original authority of the body and enlarged its membership. The close relationship with the tribes was retained thus necessitating the increase in membership. The mechanism of operation as set up by Cleisthenes continued for many years, but it lost some of its independence of action as the Ecclesie became more powerful.

The Prytany (Presidency) was filled by each tribe in turn according to lot with the first four holding of fice thirty-six days and the last six holding office thirty-five days. ${ }^{3}$ The Presidents after receiving money from the state convened meetings of the Council and the Enclesie, and the former met ever: day holidays excepted while the Fcclesia met four times in each Prytany. 4 It was the further duty of the Presidents to give written notice of the time, place, and nature of businoss on each ocoasion of a meeting. They also gave notice of the meetincs of the Fcclesia.

1. See page 38

2. Arist. Ath. Const. XLV, I-3

3. Ibid. XLIII, 2

4. Ibid. XIIII, 3

5. Ibid. XLIII, 3-4 
The Presidents also had a single Head elected by lot who held office for a single day and was not privileged to serve again. He was custodian of the public monies and documents of state being required to remain on duty day and night. Whenever a meeting of the Council or Ecclesia took place it was his duty to select by lot nine chairmen, one from each tribe, except his own, and likewise from their number a single Head. To these was entrusted the agenda and direction of the meeting. No one was permitted to be Head more than once a year, but it was possible to be Chairman once in each presidency (Prytany).

Most of the trials of officials were held by the Council especially those handling funds, and their decisions were final. An important duty of the council was the checking of the qualifications of the Nine Archons with the sovereign nower of rejection should they be insufficient. It had supervision over the navy, and shared in the administration of most other affairs. It can thus be seen that the council was a powerful part of the government of the state. 2

The Persian Wars and the Factional Strugrele. The new Constitution was not destined to go into effect without a strugele however. It faced two forces which threatened to overthrow the government at any time -- the enmity of sparta, and the growing threat of Persian expansion -- each of which involved the intrigues of Hinpias as he attempted to regain his former seat of power.

1. Arist. Ath. Const. XLIV, 1-3

2. Ibid. XLV-XLVII 
In Sparta, Cleomenes organized a new army from the whole Peloponnesus intending to avenge hinself upon the Athenians for the refeat he had suffered and set up Isagoras as tyrant. Joined with him in his effort were the Boeotians and Chalcidians, and together the three ronns pressed Athens from three sides. ${ }^{1}$ Athons, deciding to meet her most formidable foes first, marched acoinst the Peloponnesians ard wh the battle without striking a single blow, the corintians having decided not to fight and the Spartan kings having disagreed.2 Freed of the threat from the south, the sthenians turned upon the Boeotians and Chalcidians on? aiter a short war gained the victory. 3 Desiring revenge the Thebens celled upon Aegina for help, and that city in response made a serious sea raid on the Attic coast. 4

In the years immedietely following nothing of a serious nature occurred and Athens proceeded to put her constitution into operation. 5 During this time Sparta had learned of the strategem whereby cleisthenes had gained their help in overcoming the Peisistratids. Greatly angered they sent for Hippias and proposed restoring him to the tyranny. ${ }^{6}$ Calline her allies together Sparta voiced her proposition, but Corinth convinced thom that such sotion was unjust and Hinpias left the city without hoving recoived the support he had

1. Hdt. V, 74

2. Ibid. V, 75-76

3. Ibid. $V, 77$

4. Ibid. $V, 81$

5. The Constitution went into effect in B. C. 503

6. Hdt. V, 90-91 
anticipated. I Refusing offers of a tyranny in cities under the control of his allies in Incedonia end Thessaly, he retumed to his own stronchold in sigenn and awited develonments."

Havine failed in his attempts to raise assistance against Athens in Greece, uippias now went to Serdis and attempted to arrange an alliance between hinself and Persia whereby he might gin possession of the city as a dependent of that empire. Artaphrenes, the governor at Sardis, sent word to the Athenians advising them to receive Hippias back as the price of peace, but the Athenian embassy indignantly refused. 3

Drobably nothing would have cone of this refusal except for a serious revolt of the Ionien cities in 3. C. 499 , a revolt which was destined to last for five years. In the second year of the war a party of Athenians took part in an expedition which ended in burning Sardis, the capital of Asia inor. For sore reason Athens suddenly decided to aband $n$ the strugle, but the Ionians foumt on until B. C. 494 when they were finally suppressed. 4

Durinc the revolt Miltiades in the chersonesus hed been on friendly terms with Darius of Fersia; indeed, he had been friendly to the reat Asiatic nower from its first entrence into Thrace. 5 With the Ionic revolt, however, he began to face a series of mis-

1. Hdt. V, 94

2. Ibid.

3. Ibid. $V, 96$

4. Ibid. V, 99-103

5. Nepos, Milt. III, 2 
fortunes. Withdrawal of the Persian forces from the Chersonese area had removed restraint from the Scythian's who overran the country and forced hin into exile for a period of three vears. After their departure he was brovght back again and resumed his tyranny. ${ }^{1}$ Before the year was out he found himself facing the Persian fleet which had been sent to reclaim the remion now thet the revolt was crished. He must, have been suspected of taking part in the revolt by the leaders of the expedition, for we find Persians takin $r$ the aities which he had ruled. ${ }^{2}$ seeing tht his cose was hopeless iltirdes enpoged five ships, loaded them with his possessions, and set out for Athens. On the iourney one ship was lost to the enemy aboard which was his son ${ }^{3}$ but he and the remeinder of his ships reached port safely. ${ }^{4}$

In the meantime, Athens had been the scene of a great rivalry between two statesmen, Aristeides and Themistocles. Aristeides, a man of moderate circumstances, had made his reputation in the city through his love of justice. One of the nobility, 5 he was also an inti ate friend of Cleisthenes who had set up the Constitution. He was in addition a great admirer of Lycurgus the Spartan lawgiver

1. Hdt. VI, 40

2. Ibid. VI, 34

3. Apparentiy the actions of the Persians must have been a misunderstanding for the Emperor treated the captured son with distinction and even rave hir a Persian wife. See Hdt. VI, 41

4. Hdt. VI, $4 I$

5. His family had been well established in Athens as had he himself before beine g pointed to the Chersonesus by Hippias (pp. 51, 5758). See Hdt. VI, 35, 39 
whom it was his ambition to equal if not surpass. Under such conditions it was a natural thing when he favored an aristocratic form of government ${ }^{l}$ and lined himself up with the nobles in opposition to Xanthippus who had taken the headship of the people. ${ }^{2}$ Yet for all his aristocratic leanings Aristeides had no real projudices, but only sourht to do that which was just and right.

Themistocles was a man of another type. His was an obscure family with an inconspicuous man for a father and a mother who was of alien birth. 3 Nevertheless he hod a boundless ambition to be a leader in Athens, and being of no traditional party resorted to moking himself a reputation by making himself much hoard. He therefore took a prominent nart in civil suits and spoke frequently in the Ecclesia making it his business to be on hand and have something to say every time any important affair was considered. Fortunately he had a quick mind being able to see the needs of an occasion and to express his views clearly. 4

In his desire to be first it was inevitable that he should encounter the opposition end enmity of many of the prominent and established leaders in the city, and it washis fate to be opposed at most points by Aristeides. 5 of a gentle nature and conservative character, Aristeides engaced in public life to secure the best in-

1. Plut. Arist. II, I

2. Arist. Ath. Const. XXVIII, 2

3. Plut. Themistocles, I, I

4. Ibid. I, 3

5. Ibid. III, 1 
terest of the state consistent with safety and righteousness, end cared litile for favor or reputation. Themistocles, on the other hand, stirred up the people and often proposed ideas that were too bold for the cautious Aristeides. ${ }^{1}$ The consequence was a bitter rivaly in which the two men were frequently pitted against each other, Aristeides on the side of the nobility and Themistocles on behalf of the people. ${ }^{2}$ With such a bitter rivalry it developed that each man became convinced that anything his onponent advocated was faulty, and in many cases actually threatened thereby the welfare of the state.

Finally there came a time when he (Aristeides) opposed and defeated Themistocles in an attempt to carry some really necessary measure. Then he could no longer hold his peace, but declared, as he left the Asseinbly, that there was no safety for the Athenian State unless they threw both Themistocles and himself into the death-pit. ${ }^{3}$

By B. C. 493 Themistocles had gained such favor with the public that he became Archon Eponyms for the year. Conscious of the raid which had been condurted on the coasts by Aegina ${ }^{4}$ and foreseeing that the future of Athens lay on the sea, he made the rircavs into the regular port and turned Athens toward maritine empire. 5 It was his conviction that the move was a first start toward the construction of a fleet second to none in the Aegean. 6

1. Plut. Them. III, 2

2. Plut. Arist. II, I

3. Ibid. III, 2

4. See page 84

5. Pausanias, Description of Greece, I, $i, 2$

6. Thuc. I, 94 
Such was the situation in Athens when Miltiades came on the scene. Since he was a man of great wealth and had been accustomed to leadership for many years he naturally becane a nember of the nobility quickly raining the ascendancy of this party and supplanting both Zanthippus and Aristeides. ${ }^{1}$ It is possibly this new position of prominence that inspired the att $\mathrm{ck}$ on his governorship of the Chersonesus, a charge which he refuted by pointing to his enrity toward the Persians in the recent war.

The following year (B. C. 491) messengers began to arrive in Greece with the denand of Darius for earth and water in token of submission to Persian rule, and at the same time these messengers ordered the tributary oities of the seacoast to build ships of war and transports for horses. ${ }^{2}$ Themistocles gained great support with the Athenians when he caused the interpreter of the message to be arrested and put to death "because he dared to prostitute the speech of Hellas to Barbarian stipulations: ${ }^{3}$ Soon thereafter Aegina, who had allied herself with Persia, began to ravage the coast and to destroy the Athenian navy. Meenwhile Darius was completing his preparations for invasion with the constant encouragenent of the Peisistratids who were with him. 4

Soon the word reached Athens that the Persians had attacked and taken Eretria, but no steps toward defense were takan. Then the Fersians under the guidence of Hippias landed at Marathon, and

1. Arist. Ath. Const. XXVIII, 2

2. Hdt. TI, 48

3. Plut. Them. VI, 2

4. Hdt. VI, $92-94$ 
the troops were set in array by him at that place where many years ago his father had returned from exile to seize the city in battle. When the Athenians leamed of the landing at Marathon, they marched out against the enemy under Miltiades whom they had elected among their ten menerals. Once on the field the question faced the army as to the advisability of attacking the enemy or waiting for the arrival of allies. Miltiades was of the opinion that the battle should be fought imnediately and in that view he was su ported by Aristeides. 2 When the matter was put to a vote, however, the generais were unable to agree splitting the vote five to five. Everyone turned to Callimachus, the Polenarch, and tried to win his support. Fortunately for Athens two of the foremost exponents of the attack were Wiltiades and Aristeides both of the nobility as was Callimachus, and they had little difficulty in winning him to their point of view. Having waited for his turn of leadership to come around desnite the decision of the generals to waive their rights to him, 4 Miltiades marched against the Persians and gained a brilliant viotory, his outstanding leadership forcing them to retire to their ships. In response to a flashed shield, evidently a prearranged signal, the fleet sailed for Athens, but the sea attack was likewise frustrated. Failing in their attempts the Persians sailed away. The incident of the flashed shield is one of the mysteries of history,

1. Hdt. VI, 107

2. Plut. Arist. $V, 1$

3. Hdt. VI, 109

4. Ibid. VI, 110-111 
but it was clear evidence of a group of traitors within the city.

The Alcmaconids, being the most powerful group within the city,

were accused of the deed. In their defense Herodotus later said:

It is to me a thing marvellous and incredible that the Alcineennidae could ever by agreement hove held vo a shield as a sign for the Persians, desiring to make Athens subject to foreigners and to Hi pias, for it is plain to see that they were despot-haters as much as callias... who dared buy Peisistratus's possessions when they were put up to anction by the state after Peisistratus's banishment from Athens; and he devised other acts of bitter enmity apainst him. The Almaonidae were despot-haters as much as ever was Callias. Therefore it is to ne a strange and unbelievable accusation, that they of all men should have held un a shield; for at all times thay shunned desnots, and it was by their devising that the sons of Peisistratus were deposed from their despotism. Thus in ray judgment it was they who freed sthens much more then did Harmodius and Aristoriton; for these did but enrage the rest of Peisistratus's kin by killine Hipparchus, and did naurht to end the male of the rest of them; but the Alcmaonidae did most plainly set their country free, if indeed it was in truth ther by whose persuasion the Pythian priestess signified to the Lacedaemonians that they should free Athens, is I have ere now nade plain. Nay (one will say), but they bore perhaps some grud acainst the Athenian comonalty, and therefore betrayed their country. But there were none at Athens that were of better rente or more honoured than they; wherefore lain reason forbids to believe that they of all men could have held the shield aloft for any such cause. Indeed a shield was held aloft, and that cannot be denied; for the thing was done; but who did it I know not, and can sey no further. 1

It is evident from the nature of the situation thet the faction which favored trranny flashed the shield, and it is hardly likely that the Alcneeonids would have embraced a principle which they had opposed for rany cenerations on short notice. It is moh more likely 
that the group of nobles who had supported Isagoras and were old supporters of Hippias were the ones who endeavored to betray their city. Marathon, however, definitely ended these plans.

The fame of Miltiades as a result of his victory made him a popular hero, and in res onse to his request the people granted him a fleet without requiring any knowledge of his intentions. 1 Miltiades was now in a powerful position, and in view of his previous career was liable to the suspicion of aining at a tyranny. His popularity was certainly great enovgh to win such support. Xanthipous, leader of the popular group, was apparently suspicious of his intentions though powerless to offer opposition. The elashing of the shield at Marathon indicated that Hippias still had many surporters within the city, and it is entirely possible that miltiades was aiming at their support as a movement toward tyranny. At any rate he failed in his naval exnedition, and returned home with a serious wound. 2 Xanthippus now saw his opportunity and before the council of Five Hundred charged him wi th wrongdoing, presumably his failure to make rood on his promise to benefit the people. Although the counoil refused any other punishment, Miltiades was assessed a fine of fifty talents. 3 He died of his wound, however, shortly thereafter and his son, cimon, peid the fine in his stead.

1. Hdt. VI, 132

2. Ibid. VI, 134-136

3. Ibid. VI, 136 
Although it was the affair at Paros that led to the accusation of Miltiades, there was another reason for his condemnation; for the Athenians, because of the tyranny which Peisistratus had hold some years before, dreaded excessive power in the hends of any citizen. They did not think it nossible that miltiades, who had held so many and such important military comnands would be able to conduct himself as a private citizen, especially since habit seemed to have given him a taste for power. In the chersonesus, for example, during all the years of is residence there he had enjoyed unintermuted sovereignty. He had been called a tyrant, but he was a just one, since he owed his power, not to force, but to the consent of his subjects, and retained it as a result of his virtue. But all men are called tyrants, and regarded as such, who hold permanent rule in a city which has enjoyed a democratic form of government.

With Miltiades dead, the mantle of aristocratic leadership fell on the shoulders of Aristeides. 2 One of the ten generals at Marathon and second in reputation and influence only to Miltiades, his part in the victory immediately secured for him the office of Archon Enonymus, a token of his newly won leadership. 3 During his year of office he secured a remutation for the honest and impartial nenner in which he settled cases that came before him. ${ }^{4}$

At the same time Themistocles was increasing his intluence in the Ecclesia. A member of an obscure family he also had made a brilliant nark as general at Miarathon, and although young had greatly impressed the multitude. Contrary to the general opinion he thought that Marathon was merely the prelude of a bigger contest and desired to prepare Athens for the evil to come. ${ }^{5}$ This was in line with his

1. Nepos, Milt. VIII, 1-3

2. Arist. Ath. Const. XXVIII, 2. For Aristoides aristocratic leanings see $\mathrm{pp}$.86-87.

3. Plut. Arist. $V, 7$

4. Ibid. $\overline{\text { VI, I }}$

5. Plut. Them. III, 4 
policy of preparedness since he had already as Archon in B. C. 493 nrotided for the adoption of Pireeus as the naval center of the city. ${ }^{1}$ Realizing that no appeal based on the Persian threat would suffice, Themistocles pointed to the war with Aegina, and suggested that the enemy control of the sea be overcome. He pointed out that with sea rower Athens could not only overcome the Persians but become the first eity in creece as well. He proposed that the revenue from sudden discovery of a rich vein in the Laureium silver mines be devoted to the construotion of a fleet. ${ }^{3}$ Although he faced the public opposition of filtiades, he gained his point and succeeded in building a fleet of one hundred triremes. 4

The following year broucht the first clash between the two factions in a strugre over the Archonship. Probably as a result of the powerful position which Aristeides had gained throurh the office due to his reputation for honesty as well as the inagined attempt of Miltiades at tyra ny, the people seem to heve desired to prevent a recurrance of such an occasion by making it impossible for an outstandin person to be chosen as Archon. The simplest means of attaining this object was the throwine of the election to the fortunes of the lot. ${ }^{5}$ Naturally the aristocracy bitterly opposed the move. Thereupon the Eclesia engineered for the first

1. See page 88

2. Plut. Them. IV, 3

3. Ibid. TT, 1

4. $\overline{\text { Ibid. }}$ IV, 3

5. Arist. Ath. Const. XXII, 5 
time its newly acquired weapon of ostracism, and the Peisistratid leader, Hipparchus, was forced into exile, (B. C. 487). In the sane year the law was changed so that the Arohonship was to be won by lot out of the Council of Five Hundred. This alteration meant that henceforth outstanding leaders would turn their talents to other offices since merit would no longer ylay a part in gaining the magistracy. With the Archonship reduced to mediocrity its influence waned, and the leadership of the city devolved upon the Strategi (Generals) who were still elected on merit and popularity. The following year saw the ostracism of disgacles, son of Hippocrates, and in. . C. 485 an unlnown sympathizer of the tyrants was also exiled. 2

Although no significant event can be connected with these two ostracisms save the existing revolt of Egypt against Persia, it is known that Hippias was actively enlisting the Thessalians in support of Persia, 3 and it is entirely possible that the two men were implicated in an attempt to restore the former tyrant, especially in view of the aggressive tactios just pursued by the Ecclesia. When Xanthippus was ostracised in $\mathrm{B}$. C. 484,4 the leadership of the people passed to Themistoclos. 5

1. Arist. Ath. Const. XXII, 4

2. Ibid. XXII, 506

3. Hdt. VII, 6

4. Arist. Ath, Const. XXI, 6

5. Plut. Them. V, 4-5. That he already had close connections with the merchants and the Shore faction is implied from his encouragement of maritime expansion. 
Always rivals, Themistocles and Aristeides now came into serious conflict. Aristeides's rentation for justness had caused many of the people to feel that he threatened their government due to his hebit of settling quarrels before they reached the courts. Opposed in his naval policy by the aristocracy and wishing to gain complete control in the Ecclesia, Themistocles started a rumor to the effect that Arjsteides had done away with the public courts of justice through his habit of private arbitration, and had without perception established a manarchr. ${ }^{3}$ This brought forth the multitude in $\mathrm{B}$. C. 482 , and the inevitable ostracism was visited upon Aristeides in the Ecclesia. 4 This pl ced Themistocles in a preeninent position since both the aristocratic and popular factions were now leaderless in the Ecclesia.

Themistocles now continued his nolioy of preparing for the Persian invasion which seemed to be drawing nearer. With the discovery of the mines of Maronea, funts were available for strengthening the navy, and Themistocles immediately proceeded with his preparation of the city for attack. 5

At length the lone awaited attack began with the visit of the Persian emissaries and their demand for earth and water. Themistocles, having become Strategus, set about arranging for the defeet

1. Plut. Arist. VII, $l_{i}$ he probebly did this after as well as during his Archonship.

2. Aristeides was still a favorite of the lower classes

3. Cf. note I

4. Plut. Arist. VII, 1-2

5. Arist. Ath. Const. XXII, 7 
of the enery. Seeing the public desire for the presence of Aristeides and fearful lest he lend his abilities to the eneny, Themistocles introduced a bill permitting the return of 811 the exiles in order that they nicht serve their country against the Persian. At the same time they established a boundary line from the sovthem point of Euboea to the sutheastern point of Argolis within which no ostracised person might enter during his ti e exilo without absolute loss of citizenship. ${ }^{2}$ Aristeides, who even in exile had made every effort to incite the Greeks to unite in a fight for froodom, retumed to the city and forgot for the time his rivalry with Themistocles. Even thouch his enemy was Stratems with sole powers he continued to ive assistance in every way possible althrugh such cooneration elevated his rival to the chief place in the city. 3 Foreseeine the impossibllity of holding the city should the Persians rain a land victory, The istocles tried to perauade the citizens to take to their ships and defeat the enemy y sea. All his efforts thereto were in vain until the Medizing of the thessalians at the hands of Hivpias becane known. 4 Themistooles next turned to Sparta for heln, and etren gave up his naval comand in order to gein Lacedaemonian support, 5 but the defeat at Thermopylae sealed the fate of the city since the Spartans deternined to set up

1. Plut. Them. XI, I

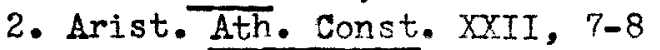

3. Plut. Arist. VIII, 1

4. Hdt. VII, 6. Hippias operated from susa.

5. PIut. Them. VII, 3 
1

their line of defense at the Peloponnesus. Hippies now ade his final offer of peace on condition thet he be received back as tyrent presumably subject to Persion overlordship, but for a last time the Athenians rejented his overtures. 2 Athens was determined to fight to the finish.

The Areopacus of all the instrinents of covernment probably the most anciont except for the Basileus was the Areopagus. Probably orivinating es council-chamber of nobles for the ancient kings, its first powers very likely were linited to control of the morals of the community, a power which it retained even under the most unfavorable circumstances. 3 Nothing is known of the original method of choosinm mership, but it is certain that the practice of passing ex-Archons into the body oricinated at an early period. 4 As the power of the Basileus waned the Areopams seized meny of his powers among wish wes the imortant function of mardian of the laws. Bilding vpon this power the Council increased in power until it resched a position of paramount importance in which it even chose the Arohons. 5

Under Draco the Areopagus found its nowers increased in two resnects. For cne thine it kept a elose watch on the Archons and prevented then from exceeding the letter of the law. Furthermore

1. Plut. Them. IX, 4

2. Hdt. VIII, 52

3. Arist. Ath. Const. I, 1

4. See pare 12

5. Afist. Ath. Const. VII, 2 
anyone unjustly treated by the magistrates could apply to the Areopagus and gain a rehearing.

When Solon leid down his lows in . C. 594 the Council was raised to on even higher position in the state. The nower to choose the Archons was taken away, but in return the Areopagites received the honor and resnonsibility of watchine over the most importent affairs of state. ${ }^{2}$ This dity included correcting offenders arginst the constitution with the right to inflict fines or other punishment in serious cases. Inder the position of guardian of the laws it had the right to try those nersons who made attompts at tyranny. 3 With all these resronsibilities and the excellence of the nembership recruited, the Areopams was rated as surpassing all other councils in the city in excellence."

Under the Peisistratids the body suffered eclipse since all of the Archons were hand ricked consisting for the most port of members of the farily of tyrants. The result was a Council which was entirely subversive to the wishes of the supreme head of the state. Then the tyrenny wes overthrow the Areopams made up of sympathizers with the Peisistratids was in disrepute and found itself more or less in the background. Eren so it could rise to the occasion should an emergency threaten as was the case when the oligarohic efforts of Isagoras were withstood. 5

1. Arist. Ath. Const. III, 5

2. Plut. Solon, XIX, 2

3. Arist. Ath. Const. VIII, 4

4. Isocrates, Areopagiticus, 37

5. See page 72 
Tnder the reorganization of Cleisthenes the Areoparus seems to have retained most of its old powers, but the emergency created by the Persian Fars torether with the interest of the people under the leadership of Thernistocles and Aristeides conspired to push the Council into the background.

We now come to an almost unbelievable develoment. So far in the conduct of the war the lower class had dominated proceedings in the Ecclesia under the leadership of Thenistocles. One eristocratic arm of the government had been subdued, namely the Archonship, and the Generalship was becoming nore and more a substitute for that official. Thus far the propress of the people had been steady; indeed, the Persien Wars were the ultirate cause of the final suocess of the democracy, but now the unbelievable occurred -- the sreopagus by a turn of fortune gained leadership of the state. '

At this date, therefore, the state had advanced to this point, growing by slow stages with the growth of the democracy; but after the Persian wars the Council on the Areopagus became powerful again, and carried on the administration hoving goined the leadership by no definite resolution but owine to its having been the cause ofthe naval battle of Salemis. 1

Seeing the Persian hosts bearing dow upon them the Athenians became panic stricken because no public money was available to finance the impending neval expedition, 2 and the generals were on the verre of giving up hope. At this point the Areopagus, still considered the foremost Council in the state, proved its excellence by coining to the

1. Arist. Ath. Const. XXIII, I

2. Plut. Them. X, 4 
rescue ond financing the expedition. ' When the battle of Salemis relieved the Persian pressure the Athenians returned to their nity to build anew. The Areopagus, heving made the victory possible, was held in high esteom, and the constitution though constantly subject to modification continued under its leadership for a neriod of seventeen years after the war. ${ }^{2}$

Development of the Ecclesia. At the sane time the Ecclesia on the motion of Theristocles had voted the return of 011 ostracised citizens that they might join in the defense of their country. 3 This generosity broucht back Aristeides, ond the two rivels were quick to join hands arainst the enemy. Since Themistocles had proved his ability as a mitary man and the just practices of Aristeides were exceeded by no one, it was arreed that the former act as meneral and the latter as his counsellor. 4

With victory at Salamis a result of the cooperation of the two erstwhile enemies, we find the Athenians bestowing in B. C. 479 the sole generalship upon Aristeides. "Having been elected general with sole powers in view of the expected battle, he came to Plataea at the head of eight thousand Athenian hoplites." 5 Joining forces with the Spartans under Pausanias the armies after a long neriod of maneuvering dealt the Persians a conclusive defeat. After the victory the Athenians retumed to their city and set about the task of reconstruction. 6

1. Arist. Ath. Const. XXXII, 1-2

2. Ibid XXV, 1

3. See page 97

4. Arist. Ath. Const. XXIII, 3

5. Plut. Arist. XI, I

6. Plut. Them. XIX, 1-2 
Themistocles desired to rebuild the city wall, and hearing of Spartan opposition personally deceived them with the aid of Aristeides until the walls were in defensible condition.

Having restored the Athenian self-confidence, Themistocles began to increase the power of the cominon people at the exrense of the nobles, and the new naval policy, drawing the people into the city placed the controlling rower in the hands of those engaged in seafaring. 2 It was later said that maritime empire mothered the Athenian democracy. 3 Another nlan for securing naval domination through burning the Hellenic fleet was checked by Aristeides, 4 who hoving the confidence of the Ecclesia, refused to give his consent to the project. Themistocles now began to favor a more independent course for Athens and tried to destroy the Spartan hecemony over Greece. In return the Spartans tried to advance young Cimon, Son of Miltiades, in public favor and make him a political rival of Themistocles. 5

... isince he (Cinon) displayed brilliant and heroic qualities in the actual strugele at Salamis, he soon acquired reputation and good will in the citb...so when he entered politics the people gladly welcomed him, and promoted him...to the highest honors and offices in the city, for he was engaging and attractive to the common folk by reason of his centleness and artlessness. But it was Aristides... who more

1. Thuc. I, 90-91

2. Plut. Them. XIX, 4

3. Ibid.

4. Ibid. XX, 1-2

5. Ibid. $\mathrm{XX}, 3-4$ 
than any one else furthered his career, for he saw the fine features of his character, and made him, as it were, a fojl to the cleverness and darins of Themistocles. 1

Meanwile Aristeides, seeing the desire for a more popular form of government, introduced a decree recommending that the administration of the city be extended to all classes and that the Archons be chosen from all the Athenians, ${ }^{2}$ but nothing seems to have come of this proposal which was probably blocked through the influence of the Areopegus. Aristeides now joined with Cimon in the expedition against the Persians, and upon the misconduct of Pausanias, the Spartans decided to give up their leadership of the expedition abandoning Hellenic leadership against the Persians to Athens. 3 Aristeides now, upon sugrestion of the Allies, assessed the cities according to their wrth and ability to pay, and thus instituted the Delian Naval Lague (B. C. 478$).^{4}$ As a part of the agreement all of the cities swore with Athens to have the same enemies ond friends, 5 and a common treasury was established at Delos which was to be the meeting place of the League. Since collection of the "tribute" was entrusted to the Athenians they created the office of "Treasurers for Hellas" who took charge of the funds thus produced. 6

1. Plut. Cimon, $V, 4$

2. Plut. Arist. XXII, I

3. Plut. Cimon, VI, 1; olso Arist. XXIII, 1

4. Plut. Arist. XXIV, 1

5. Arist. Ath. Const. XXITI, 4-5

6. Thue. I, 97 
Aristeides also played an important part in the development of the Ecclesia when he advised the people to come down from their farms and live in the city thus keeping their leadership of the city.

...he began to advise them to aim at the leadership... telling them that there would be food for all, some serving in the army and others as frontier-guards and others conducting the business of the community, and then by this method they would keep the leadership... They...established a plentiful food-supply for the multitude, as Aristeides had proposed; for the combined proceeds of the tributes and the taxes and the allies served to feed more than twenty thousand men. For there were six thousand jurymen, one thousand six hundred archers and also one thousand two hundred cavalry, five hundred members of the Council, five hundred guardians of the dooks, and also fifty watchmen in the city, as many as seven hundred officials at home and as many as seven hundred abroad; and in adition to these, when later they settled into the war, two thousend five hundred hoplites, twenty guard-ships and other ships conveying the onards to the number of two hundred elected by lot; and furthernore the prytaneum, orphans, and werders of prisoners -- for $21 \frac{1}{3}$ of these had their maintenance from public funds.

While Themistocles and Aristeides were engaged in exranding the power of the people and were strengthening the posit on of the Ecclesia, Cinon the young leader of the nobility was buldine a reputation as a military leader, and with each successive victory his influence in the Ecclesie rrew. One of his exrly achieverents was the discovery of the bones of a ciant which were identified by the Athenians as the remains of Theseus. The bringing back to the city

1. Arist. Ath. Const. XXIY, 1

2. The town hall

3. Arist. Ath. Const. yXIY 
of the remains was said to be the chief reason for his popularity with the comon folk. ${ }^{l}$ Another means by which he courted popularity. was the opening of his fields to all passersby that they might partake of the fruit of the land plus a daily dinner given at his house to which any poor man who wished micht come and receive a free meintenance. 2 Thus his popularity with the masses Erew, and yet he was the last great champion of the aristooracy, and as Aristeides's protege succeeded to his position of loadership.

With the support of the Alcneeonids and others, cinon engineered a charge of Medizing against Themistocles as a means of offsetting his powerful leadership. 4 The peonle, already jealous of Thenistocles's strength began to welsome these slenders, and his earlier attempts to extract money from the allies were now renembered against him. The sequence is easily seen. Tis self-conceit and constent recital of his achievements soon becane tiresome, and a finel charge brought against him by the aristocratic combination brourht about his ostracisin. About four years after this Aristeides pessed fron the scene 7 in death.

Cimon was now sunreme and meintained the power of the Areopagus. Every challenge was successfully met throng his brilliant reputation as a military leader. Courting the friendshin of Sparta was a basio

1. Plut. Cimon, VIII, 6

2. Ibid. $\overline{X, I}$

3. Ibid. $\mathrm{V}, 4$

4. PIut. Afist. Xxr, 7

5. Plut. Them. XXI, I

6. Ibid. XXII, 1,3

7. $\overline{\mathrm{NeOS}}$, Aristides, III, 3 
poligy, and so long as he remained successful with the Spartens in cooperation his aristocratic position and leadership were secure. Downfall of the Areopegus. Cimon had not maintained the power of the Areopagus without opposition. Some time before his ostracism, Thenistocles had coneived an eversion for that hody even though he was a nember. ${ }^{2}$ In all probahility this con be traced to his loss of influence with the nobles and the increasing sandals connected with his nome. At any rate he seems to have plotted the downfall of the last stronghold of the aristocracy. At the rame time the people appear to have tumed from him and adopted for their leader one Ephialtes 3 who had a revutation as one of extreme honesty. 4

The istocles now thought thet he saw an opportunity to rid himself both of the aristocratic council and his newly-found rival by pitting them against each other. He, therefore, informed Enhialtes that the Areopagus was planning to arrest him whilo he informed the Areoparites that certain persons were consuiring to destroy the Constitution, indicating to certain members the meetings (probebly political) which were taling place at his rival's residence. 5

Themistocles and Enhialtes now began to denounce the Areoparus before the Council of Five Hundred and later before the Ecclesia. 6 Their efforts seen to have been nremature, however, and Cimon's in-

1. Plut. Cimon, XVI, 1-2

2. Arist. $\Lambda$ th. Const. XXV, 3

3. Ibid. XVIII, 2

4. Ibid. XXV, 1

5. Tbid. XXI, 3

6. Irist. Ath. Const. YXV, 4 
fluence together with Themistocles's growing unpopularity gained the ostracism of the latter. 1 Ephialtes evidently remained suspicious of the Areoparus, but in face of Cimon's ascendency seems to have been content to derelop leadership of the people ${ }^{2}$ while awaiting an opportunity to continue his attack.

In the following ei hht or nine years ciron continued supreme. His naval career was one onstant series of successes. Seeing the Delian allies little inclined to provide their portion of ships and men, he consented to accent as a substitute money to defray the exnense. With this moner new ships were built and manned by the Athenians themselves. Thus, Athens was becoming more and more predominant in the League. 3 When llaxos withdrew from the League, Cimon suppressed the revolt, and Naxos found herself in consequence a subject instead of an ally. The revolt of Thasos had the same result. Thus by degrees ction was chenging the League into on empire.

Cimnn's career at length met with an effectual check. Iphialtes had formed an alliance with a young and rapidly rising nember of the Alomaonid family -- Pericles. ${ }^{4}$ Doubtless enonuraged by Enhialtes, Pericles challenged the accounts of cimon ${ }^{6}$ following the reduction of Thasos, and Cimon, although acquitted of the charge, seems to

1. Plut. Cimon, $\mathrm{X}, 7-8$

2. Arist. Ath. Const. XXVIII, 2

3. Plut, Cinon, XI, 1-3

4. Hdt. VI, 131

5. Plut. Pericles, $\mathrm{X}, 7$

6. Arist. Ath. Const. XXVII, I 
have lost some nart of his popularity. 'The trial seems also to have secured the future for Dericles because he imrediately gained stature with the populace and loomed as their eventual leader. Ephialtes now saw his long awaited opportunity to contihue his attack on the Areopagus. ${ }^{2}$ Forming an alliance with Pericles he directed another attack against the nobles, but as had been the case in all previous attacks cimon menared to keep the people in check. 3 He was however first and foremost a general, and duty called him away once nore, this time with succor for the Spartans who were in the throes of a Helot revolution as a result of the confusion accompanying a recent earthquake. ${ }^{4}$ This time Cimon's system of control broke down, probably through the rising popularity of Pericles, 5 and Emphialtes takin the lead ${ }^{6}$ dirested the attack against the Areopagus. This time his effort succeeded. Persuaded of the disproportionate authority of thet body, the Council of Five Hundred heard the charges, was convinced, and passed the matter on to the Ecclesia. There the matter was a foregone conclusion. With Cimon absent and the nobles leaderless the blow fell. Enhialtes attacked various members of the Areopegus through the Heliaea and brought about their retirenent. " With the whole body thus suffering in esteem the Ecclesia proceeded to deprive the Are-

1. Plut. Cimon XIV, 2-4; XV, I

2. Paus. I, xxix, 15

3. Plut. Cimon, XV, I

4. Ibid. XVI, 7-8. Enhialtes opposed the relief expedition

5. Plut. Per. IX, 3-4

6. Plut. Toralia, $802 \mathrm{D}, 805 \mathrm{D}$; also Per. VII, 5-6

7. Arist. Ath. Const. XXV, 2 
opegus of all its added powers legving it only the ancient right of supervision over the public morals. Joining with Pericles he made himself master of the Heliaea which had been effectively opened to tho neople by Pericles when he instituted payment for service in it. ${ }^{3}$ This payment for Heligea duty made possible active participation by the Thetes by affording to them a recompense for time lost from their faming duties. By urging the people further towards naval nower Pericles created additional interest in the masses who became all the more interested in controlling the govermnent. ${ }^{4}$ It is also probable that at this time the counoil of Five Hundred lost its sovereign power to pass verdicts of ouilt and sentence being henceforth reguired to submit such findings to the Heliaea through the Thesmothetae. 5

With the people now in full oontrol of the government Enhialtes and Pericles were now roady for the return of cimon. When he came back and attempted to restore the Areopagus to its old position of influence the people withstood him. 5 The refusal of soarta to accept the solicited help of $\Lambda$ thens amainst the Helots brought into disrepute Cimon's long advocated policy of friendship for Lacedaenon, and the populace in fury ostracised him. 7 Enhialtes did not long survive his triumph for shortly thereafter he was

1. Arist. Ath. Const. XXV, 2

2. Plut. cimon, XV, 1

3. Arist. Polit. II, ix, 3; also Ath. Const. XXVII, 2

4. Arist. Ath. Const. XXVII, 1

5. Ibid. XIV, I

6. Plut. Cimon, XV, 2

7. Ibid. XVII, 2 
murdered, apparently at the instigation of the aristocracy, but their cause was hopeless. ${ }^{1}$ Pericles was now undisputed leader of the people, and the oponing of the Archonship to the Zeuritae completed the democratic triumph. 2

State of the Democracy in B. C. 457 The Constitution at the accession of Pericles had undergone important changes, When compared with the work of cleisthenes the contrast is great. Whereas the latter had left the covernment largely aristocratic, the state had now become genuinely demodratic. The Archons were now entirely subservient to the will of the peonle, and in their degraded position no loneer played an important part in the administration. 3

The Areopagus, stripped of its administrative powers, retained only its ancient prerogative of supervising the public morals. 4 The Council of Five Hundred, divested of its sovereign powers of fine and punishment was subject to the will of the Ecclesia operating nore or less as a conmittee. 5 The center of all power in the state now rested with the Ecclesig consisting of the sovereign neople and therefore expressive of their will. ${ }^{6}$

The Heliaea was the guarantee of the people's power and had ultimate deoision as an appeal body. ${ }^{7}$ Under complete control of the people the Courts served to back up the decisions of the Ecclesia.

1. Plut. Per. $\mathrm{X}, 7$

2. Arist. Ath. Const. XXVI, 2; in 3. C. 457

3. Due to the functioning of the lot.

4. Arist. Ath. Const. XXV, 2

5. Ibid. XIV, I

6. Arist. Polit. II, Vi, 12; see also Hdt. II, 80

7. Arist. Ath. Const. XXIV, 3, XXVII, 2 
The position of leadership had been transferred from the Archonship to the Strategi, but even though he was the agent of leadersip the Stratemus was subject in most cases to the will of the Ecolesia which appointed him and supervised his activities. ${ }^{1}$

In the hands of Pericles, then, the Athenian Constitution had becorne a democracy in which the people ruled and were destined to mile until overcome by Alcibiades, a descendant of the same fanily which had been resnonsible for the new onnstitution and the institution of the democracy. Cleisthenes's Constitution in B.C. 457. The Archonship was much weakened by B. C. 457 alth ngh the ethod of eleotion was not rreatly changed. The tribes still elected ten candidates each, but the method was by lot ${ }^{2}$, and the nine Archons were chosen from them hy lot. 3 The Zencitae were ednitted to the preliminari rolls from which the Archons were chosen. 4 The election took place in the Eanesia and the of icers were calle to account by that body. Prospective Archons were still subject to a qualification check by the Areoparus, but had now the right of a peal to the Ileliaea. 5 The term of office was one year without the nrivilege of reelestion.

The familiar distinctions of Archon Eponymus, Basilevs, Polemarch, and Thesmothetae remined, but their public functions were greatly

1. Thuc. II, 65; Plut. Per. XVI, 3; also Mor. $802 \mathrm{C}$

2. Arist. Ath. Const. VIII, 1

3. Ibid. The method by which the motes were excluded is not definitely known.

4. Ibid. XXIT, 2

5. Ibid. XLV, 3 
limited. The Archon Enonymus still retained certain ceremonial duties such es appointing the choms-leaders for the tragedies, and the Polencroh still retained his encient ancestral duties connected with the war responsibilities, 'but his leadership of the army seems to heve been eliminated. The Basileus retained his ancestral rights and religious duties, but as he had already been reduced in early tims nothine, remained to be done to him. It is probable that even the power to pronounce curses had been circumscribed. The Thesmothete held the preliminary trial in lewsuits end seem to heve had little power to do anythin else. 2 In other words the Archonshin had been reduced to a rroup of officials who had nothing but routine jobs to perform.

The Areoparus still sontainod only ex-Archons who were life members, but they had been sheared of all imnortant powers. Individually the nembers were subject to attack and retirement through the Heliaea, 3 and leave of absence still remained to be gained only by a plication to the rovermment. The old council still retained the rower to sunervise the public morals, 4 and its ancient rights of trial of: sacrilege and murder cases remained. Other than this little remeined since all the added rowers of safegnarding the Constitution had been renoved by Enhisltes and Pericles. 5

1. The specific duties are unknow

2. Arist. Ath. Const. III, 5

3. Ibid. XXXV, 2

4. Ibid.

5. Ibid. 
The Council of Five Hundred consisted of five hundred nembers, fifty from each tribe all chosen by lot from the three upper classes although this latter renuirement seems to have been imored. As before no porson could hold office a second time until the entire list of eligibles had been run through, and the lot was open to citizens thirty rears of age or older. The members were subject to an oath of industion, and failure to attend the meetings resulted in a fine. The counoil, like the Areopags, hed lost most of its imnortant nowers. Verdicts of puilt and penalties passed in connection therewith had to be submitted to the Heliaea by the Thes2 mothetae, and the nower to reject officers-elect was also subject to appeal to the Heliaea. 3 The Council retained nower of the Naucrariae, 4 and still had some control over actions of the Strategi, but its main business was the consideration of subjects to be introdnced to the Ecclesia. 5 This latter function seems to have lost much of its potency, and it is probable that the council acted in this respect as a comittee effectively controlled by the now more powerful Ecclesia.

The legislative power now was onmletely in the hands of the Ecclesia. It wa connosed of all grouns -- tredesmen, farmers, and nobles, -- and group action seems to have taken place by faction

1. Arist, Ath. Const. VII, 4

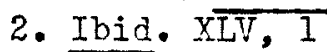

3. Ibid. XIV, 3

4. See page 31

5. Thuc. I, 45 
leaders, the so-celled "heads of parties." The body was convolred by the strotegi $i^{1}$ who received their appointment through it, ${ }^{2}$ and arbitrated all counsels. 3 It held the sovereign power in the state and used those powers to dethrone the sreorggus and limit the council of Five Hundred. It was a deliheretive body, and although all topics were subject to previous action by the Council, the Ecclesia had final decision as to the agenda. It had the power to provide for safety of individuals and therefore of the state, and the device of ostracism took place under its supervision. The Ecolesia was certeinly the "center" of the govermment in Athens.

The Heliae was considered by the pople to be the roundation of their democracy. It was a system of courts of justice controlled by the peonle and representing all classes. The juries consisted of at least three hundred members, and every citizen had the right of enpeal to the courts. The jurors were elected by lot, and by the time of Pericles were being paid for their services. 5 As umpire in $a l 1$ disputes nublic or privete the Heliaea wes the source of the people's power. A third person could introduce to the Helisea any dispute between two othor individuals. The Heliaes had a check on everybody and evory organ of rovemment except the Ecclesia. The Thesmothetae were reguired to submit final hearings to it; all cases in the Council of Five Hundred could be appealed to the Helizea;

1. Thuc. II, 59

2. Xenophon, llemoriabilia, II, vi, 38

3. Hdt. III, 80

4. Thuc. I, 45

5. Arist. Polit. II, ix, 3 
and disputed cases of disqualifications of officers by the Areopagus could be heard. The only legal groups not eleoted by the people were the Local Justices, and they wore elected by the Council of Five Hundred $^{2}$ which wes itself subject to Ecclesia pressure.

The power of administration still remained with the Ecclesia, but on rare occasions a dominating personality such as Pericles or Themistocles could under favoreble circumstances direct public affeirs almost at will. These men as strategi worked in close conjunction with the Ecclesia through which they were appointed. Their election took place by tribes, each of which provided one Strategus. Although the Polemarch was closely connected with the strategi, his power seems to have been curtailed for he is never mentjoned and must have had only a religious signifioance. In cenerel these military loaders were subject to the supervision of the Foclesia by which they could be fined or removed, but the Strategi seem nevertheless to have had power to sonclude treaties without consent of the Icclesia even though contrary to general opinion in the sovereign body. 2 That the strategi had superseded the Archon Eponymus in administrative leadership cen be seen not only in his active leadership, but also in the fact that he convened and presided over the Ecclesia which wes now the most important body in the state. 3

1. Arist. Ath. Const. LIII, I; XXNI, 3. They were chosen by lot. 2. Thuc. I, 6I; II, 70

3. Ibid. II, 59 
The Heliaea. In the Athenian mind the whole democracy could be explained in terms of the law courts. This belief probably arose from the fact that in the period from Pericles on, the courts could be seen actins as a check on practically every egency of the rovermment. The Archonship was limited in that the Thesmothetae were required to submit everything to the courts, holding only preliminary trials. The hreopamus had been stripped of its powers and retained only ceses involving sacrilege and homicide under its jurisdiction. The Council of Five Hundred hat lost its sovereign power to fine an punish, being required to submit its findings to the courts. Furthernore, a citizen had the free right of annealing any case from these agencies to the juries for final decision. Only the Ecclesia, the sovereign people collectively, were above the Heliaea.

In the formative period of Athenian history we find the judioial powers in the hands of the king and the Council. As the nobility circumscribed the powers of the monarchy, the judicial powers come to be concentrated more and more into the hends of the Archons and the Areopagus until scarcely any power romaingd to the Basileus except certain religious duties. As power became concentrated in the hands of the Archon Eponymis he tended to gather in his hends the judicial duties as well as the administrative responsibilities. The action of the nobles in diridine these two powers and creatinc the six Thesmothetae was a first move toward the emancipation of the court system. The Junior Archons (as the Thesmothetae were 
sometimes lnown) were entrusted with the recording of the public laws and thus preserving them for use in the trial of litigants. 1 Under solon the power ff these officials was expanded so that they were empowered to give final judment in lawsuits. This power was retained until the onsleucht of the Periclean demooracr, and even then the Thesmothetae continued to hold preliminarr trials. 2

The first real appearance of the Jury Court as a popular device can be traced to Solon. As a part of his reforms bolon divorced the law courts from the other parts of government and mado them indenendent throwin. the election for membership open to the lot. ${ }^{3}$ All classes were nemitted to serve as jurors, even the lowly thetes, and everyone wes pemitted the privilege of apperl to the lifieliees even from the rindings of the megistrates. ${ }^{4}$ It was further permitted thet every citizen mi ht exeroise the privilepe of entering suit in behalf of eny injured rerson. "If a men was assavited and suffered violenoo or injury it wes the pritrilere of any one who had the ability and the inclination, to indict the wrons-doer and prosecute him." Thus it came about that the Feligea had the final soy in all logal matters public or private. Accoritne to pluterch: -..it is said that his laws were obscurely and ambignously worded on purpose to enhence the power of the popular courts. Eor since parties to a controversy could not get setisfaction from the laws, the result

1. Arist. Ath. Const. $\mathrm{XXX}, 4$

2. Ibid. III, 5

3. Arist. Polit. II, ix, 3

4. Plut. Solon, XVIII, 2

5. Ibid. XVIII, 5

6. Arist. Ath. Const. IX, 2 
was that they always wanted jurors to decide it, and every dispute was laid before them, so that they were in a manner masters of the laws.

Thus we see the reason why Athenians considered tho Heliaea to be democratic and a source of the peoples' power. It was open to all classes and har ultimate decision in ell matters of legal dispute. Yet, the fact that the Thetes wers unable to leave their farm duties and come to the city to exerciso their legal rights without financial loss negated the practical velue of the set-un.

Tnder Peisistratus the law courts continued to function in their normal manror, though restricted by the trrant. Yowever, it is not likely that they suffered seriously, since there wes little occasion for them to conflict with the Peisistratid system. 2 The courts do seem to have undercone an expansion, for we have seen that he organized a roun known os the Local Justices as a consequenco of his increase in revenue. 3 These cnnsisted of thirty iudges who went on circuit and tried cases in each of the districts (1ater demes) ${ }^{4}$ thus making it possible for the citizens to obtein iustioe without taking the trouble to jonmey to Athons. The Local Justices were anparently abolished efter the expulsion of Hinpias, but were instituted agrain by Pericles in B. C. $453 .^{5}$

1. Plut. Solon, XVIII, 3

2. Due to the onoration of the Locel Justices

3. Arist. Ath. Const. XII, 4-5

4. Ibid. IIII, I

5. Ibid. XXYI, 3; possibly a means of serving the increasine number of non-citizens flowine into Athens. 
There is no evidence on the Heliaed for tho ceriod of cleisthenes, but it is certain that they were functionine durine the entire time and, further, that the courts were held in hi ch esteem by the reople. It is interesting to note that mernistocles in his effort to secure the ostracism of Mristeides arrealed to this feeling when he accused his rival of abolishing the "public courts of Justice by his setemining and judring everything in private." ${ }^{1}$

The Heliaea reached its final state of mowth under Pericles. When with Ephialtes he took nart in the overthrow of cinon, the Courts were his principal target. Desirino to find a counter-dovice against Cimon's wenlth, Pericles used the publio fonds to ain popvlarity ${ }^{2}$ and the principls of the paid jury court was his solution to the problem. 3 Thus were the neople finally able to take the Heliee completely in their ow hends. "With a panel of six thousand jurymen aveiloblo, 5 and assurance of pry for service the citizen no longer faced a loss when particinatine in jur service, and was ahle to serve at every onnortunity thet peforded.

The result, then, was a court ysten thet dominated al instruments of movernment snve the Ecclesis. The Thesmothetae wore able to hold only a preliminar triel in lawsuts with the final docision in the hands of the Heligea. 5 The Areopagus wes powerless to oppose

1. Plut. Arist. VII, 1

2. Plut. Per. IX, 2

3. Arist. Ath. Const. XXVII, 2

4. Plut. Cimon, XT, 1-2

5. Arist. Ath. Const. XXIT, 3

6. Ibid. XI!, I 
popular will. Although the Council of Five Hundred hed received the old power of the lreoperus to check the gualifications of those persons elected to hold office the following year, it no longer had sovereion power to reject the disqualified, but had to subnit to possible appeal to the courts. ${ }^{1}$ only the Ecclesia withstood the all embracing authority of the Heliaea, and it was exempt only because it, too was composed of the people. Othorwise the Heliaea was supreme.

The Strategi. Althoum the democracy hat triumphed and all power was in the hands of the poople, it was possible for powerful men to control the covernment. The Areopagus and council of Fivo Hundred had fallen before the democratis notement, and was forced to eclnowledge the sunremacy of the Ecclesia. Whe Archons were compelled to submit thoir judioial Pindines to the Heliaea for confirmation or rejection and in general were efectively checked. Yet the two omencies of the common neople were handicanod. The law courts (Heliaea) wile able to protect the individual rights of the citizen-boiy end rrevent encroachment on the laws wero by their neture unsuted for loadership an unfit to carry on an administration. The Ecclesia althouch holding the sovereign power in the stete suffered from the lack of an official leader who could be certain of retainin his nosition for a set period of time. The Archon Eponymus hat throveh the lat bean demraded to a nosition of

1. Arist. Ath. Const. XIV, 1-3 
iupotence since the holding of the office was now purely a matter of chance. Under the circumstances leadership had to come from some part of the government, which could provide both a stated term of service and a means by which the most fit micht be selected. The answer to both requirements was found in the Generalship.

The Strategi were the result of a lons perind of evolution as was true of all other Athenian coverning acents. In the early legendar period ell military power had been entrusted to the kinss, and the mythical rulers were for the most part mon of wailine oharacter. ${ }^{1}$ The creation of the Polemarch was a step which separated the militery and aministrative powers. The new officor by mivin his w ole attention to military affairs wes able to rovide for defense much more easily than the earlier all-embracing kingsip since the choice of a man fitted to the task was possible, and the element of cowardice was limited to a rreat degree. 2 creation of the six Thesmothetae eliminated his legislative duties, and from about B. 630 the onlemroh was purely o military leader with only those judicinl powers traditionally connected with his office. 3

Wnder the laws of Draco wo find a new roup of military men appearing on the scene -- the Strategi or Generals. They were elccted by the citizen-body from those rersons who vossessed an unencumbered estate worth et least one hundred minae and who had lecitimate sons

1. Theseus is the type of tho hero king

2. Arist. Ath. Const. III, 2-3

3. Ibid. III, 4 
over ten years of age. We also see that these new military leaders were required to submit to an anmal accountine to the people as was the case of the other elective croups. 2 It is not lefinitely stated that these mon were constitutionel officers, but the importence of their nosition plus the system of gualification and anit sems to imply such status. 3 Under Solon we find that the nosition of the Strateri is raised in dipnity and that the Thetes wore prohibited from serving as such. 4

Under Cleisthenes the Strateri were elected by the tribes with one from each tribe. 5 This definitely puts the generalship on a constitutional hasis for we find then subject to the same checls, the same property cualifications, and the same method of election as other officers. Indeod, judeine from these remiremonts, it rould seem that they were anmroachind the Polemerch in importance and classification even though that officer continued to direct the whole army ond was therefore leader of the armed forces. officially the ten Strategi took their nosition in the corernmental set-up in B. Q. 501 . At some time during this neriod the election of the strateri took place in the Council of live Hundred, and the fact that election is by show of hands indicates the practicnl importance of the office with each men selected on a basis of merit rather then chance.

1. Arist. Ath. Const. IV, I-2

2. Ibid.

3. Ibid.

4. Ibid. VII, 4

5. Ibid. XXII, 3

6. Ibid. XXII, 1-3

7. Ibid. IXI, 1 
With the Persian War period we see a constant increase in the power of the Strategi and a corresponding waning of influence of the Polemaroh. In tho popularity of Miltiades we see the possibilities of leadership through the office when a person of strong personality and reputation held it. It is interesting to note that Miltiades was appointed through the influence of the people ${ }^{1}$ and that he was ranked as least influential. ${ }^{2} Y_{\theta t}$ his experience was such that he commanded the respect of all, and when the ten friled to agree upon the nolicy at Harathon it was the persuasion of Miltiades which won over Callimachus the Polemarch (who held the deciding vote) and led to a determination to do battle. 3

The prerogatives of the cenerals in 3. C. 490 is interesting. The Polemaroh is still nominal leader of the army holding the honorary first position of command or the right wing, 4 but it seems that he had little power to determine military policy since his vote was only needed should it be reouired to breal a tie amons the ten. 5 We further see that the officers were oraded with the Polemarch in position of honor and the Strategi rated fram himest to lowest. Also it harpened thet the Stretegi tool turns at leading the forces with each taking a day in tum. This tredition was evidently so strong thet Miltiades hesitated to accept the rights relinquished

1. Hdt. VI, 104

2. Ibid. VI, 103

3. Ibid. VI, 109

4. Ibid. VI, 111

5. Tbid. VI, 109 
to him by others, but preferred to wait his own turn bofore doing battle at Marathon.

Inder Themistocles we find the Strategus in control of the government. In this cepacity he actually seems to have carried on the administration subject to criticism and moral restraint from Aristeides -- another strategus.

From the time of the bottle of werathon we find that the leaders of Athenian nolicy are Streteri. Themistocles, risteides, cimon, Pericles -- each determined publio noliey throuch control of the military leadership. Themistocles without a definite factional ali gnment managed to keep control subject to the veto of Aristeides. Aristeides manoged to keep moral control of the situation until his death. Cimon throuth his succession of brilliant victories kept control of the situation for nine years until his defeat at the hands of Pericles -- another Strategus. The Generalship with its possibility of continuous reelection was the only agency through which a unified and consistent nolicy might be maintained, and the pressure of external politics forced Athens to acquiesce to such leadership. By the time of Pericles we find the Generalship at tho apex of its influence. The Strateri were in close tonch with the Ecclesia, and worked through that popular mroup. They were appointed by the Ecclesia ${ }^{2}$ and were subject to its will, beine compelled to submit to fine or removgl if the people felt such measures necessary. ${ }^{3}$ on the

1. Hdt. TI, 110-111

2. Xen. Nem. II, vi, 38

3. Thuc. II, 65 
other hand the Strategi were empowered to convene the Ecolesia and to conclude treaties apparently at times wi thout consent of the sovereign body. ${ }^{3}$ Thus by degrees had the General emerged from obscurity and climbed to a rosition of preeminence in the state.

Pericles as Leader of the State. Pericles throurh his lons tenure of the office of strategus held control of the stete and through wise use of his position wes nracticelly an autoorat. He was a nan of illustrious ancestry. His father was Xenthippus, a former leader of the popular party, and his mothor, Agariste, was an Alcmaeonid and niece of cleisthenes the law-giver. 4 Thus by ancestry he was connected with the merchent and popular factions, possibly an important factor in his later influonce nnon the reople; ret, ho was by nature of an aristocretic and sensitive noture. As a younc man he was said to resemble peisistratus closely in epnearance and menner. ${ }^{5}$ With a brilliant linease and powerful friends, Eericles feared thet entrance into rublic life might lead to ostracism, so he tumed to a milita career as an outlet for his telents. 6

Though breve and enterprising he aroided public ife until the death of Aristeides and the banishment of Themistocles had removed the most formidable opposition. Then with cimon away from the city

1. Thuc. II, 59

2. Ibid. I, 61

3. Ibid. II, 70

4. Hdt. VI, 131

5. Plut. Per. VII, 1

6. Ibid. VII, 2 
with his Iong campaigns, Pericles thrucht that the proper time for his entrence into politios wes at hand. Unable to match the reat wealth of Cimon, he espoused the cause of the poor, allied himself with Ephialtes, audaciously attacked Gimon in the Fcolesia, ent soon became a powerful champion of the people. In order to match the generosity of Cimon he devised the plan of using public inonies for public services. 2 In the course of this activity payment for jury duty wes institited, and the objections of pimon were met by the ostracism of that aristocratic loader. ${ }^{3}$

And soon, what with festival grants and jurors' wages and other fees snd laresses, he bribed the multitude by the wholesale, and used them in opvosition to the council of the Areiopams. Of this body he himself wes not a nomber sinco the lot had not mede him either Eirst Archon, or Archon Thesmothete, or Kine Archon, or Archon Polemerch. These offices were in ancient times filled by lot, and through them those who properlir acmitted themselves were promoted into the Areiopegus. For this reason all the more did Pericles, stronm in the effections of the people, lead a successful party ageinst tre council of the hreioparus. Tot only was the Council robbed of most of its jurisdiction by Ephialtes, but Cimon also, on the chares of being a lover of Sparta and a hater of tine people, was ostracized ... Such was the power of Pericles anon the people. 1

With the death of iphieltes by assassination Periclos was master of Athens. Yet he never made himself too femiliar with the public. It was his policy to avoid public contact except on important occasions when emerencies were at hand. Otherwise he refrained from speaking in the Fcclesia or addressin the neople preferring to carry

1. Plut. Per. VII

2. Ibid. $\overline{\mathrm{IX}}, 2$

3. Ibid. IX, 3-4

4. Ibid. 
out his mblic policies throw his friends end with public speakers as enents. It was this ten lency of his wich led the Greels to attribute all harpenines in Pericles's time as enenating from his leadershin. This probably accounts for the designation of rohialtes as a tool of Pericles when in all probability the case was just the onposite. By such means pericles was able to control the popnlace. Iie held his position as leoder for forty years mostly by means of his anmul occunaticn of the office of Strategus wich he held on one occasion for fifteen successive rears. 2 te wes not entirely mithout opposition, however. Thucydides ${ }^{3}$ met with ostracism ot his hands, w. and on another cocasion he was fined and ar arently severel censured by the Ecclesia, but the followine year witnessed his reelection and continued control of all nublis affairs.

Because of this mervelous control of the ponvlace and his continued success es a holder of the office of Strategus, his position resembled that of the princeps under Aucustus Caesar -- an implicetion apparent to at least one writer of the imnerial neriod at Rome. 5

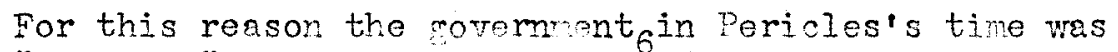
"in nome," as Thucrdides says," "a denocracy, but in fact the rile of the foremost man," beceuse of his nower of speech.

1. Plut. Per. TII, 5-6

2. Ibid. XTI, 3

3. Tot to be confused with the historian of like name

4. Thuc. II, 65

5. Plut. Mor. $802 \mathrm{C}$

6. Thuc. II, 65

7. Plut. Mor. $802 \mathrm{c}$ 
WIY THE DEMOCRACY GREW AND T R I U P P P E D 
PART IV

WIY THE DEMOCRECY GREW AND TRITIPHED

The democracy develoned in Athens only after a hard strumle. It grew as did the Constitution -- step by step. The first gains were irsignificent and at sirst sicht do not a pear demncratic, but every checl on an official, or every restriction on unresponsible power was a move towerd the nltinate coal of mule $b$; the poeple as exemplified in the Ecclosia and the Yeliaea. Nobility checked royalty, and the traders and merchants checked the nobles. As the two latter eroups strugeled for nower thoy barnained with the common people. As the common people developed leaders, they began to develop nower, and once they realized their strength they were invincible. The first sten towards democracy was the srowth of the nobility at the expense of royalty. The early kings were absolute milers able by their might to inspire feor and respect thus geining their ends through superior might. ${ }^{l}$ They ruled by divine right and were descended from the gods throurh some great hero. In the unification of Attica we see the method by which the nobles stripned the kin: of his power. ${ }^{2}$ The king seeks to centralize or otherwise strengthen

1. Plutarch, Theseus, XXIV

2. Ibid. XXIV 
his power, but to attain his end he must dive somethins in retum -in this instance he rrants a council chamber to the nobles. Even so he holds all of the powers. He is commander in war and ruardian of the laws, and in addition knows the will of the rods thus servine as a religious leader. It was un to the nobility to bring the kine dow to their level by stripning hin of his privileres until he reteined no advantages more than they.

The first attack on royelty wes directed at the hereditary right of the sovereign, and the institution of nore than one royal house was the first step in the reduction of the royal euthority. 1 The second onslaught robbed him of a great pert of his religious authority when nobles rained the control and caro of the roligious rites in the city. ${ }^{2}$ Next came the mowledce of the laws of the state swiftly followed by control of the mamistracies which interpreted those laws. "Having token his halo away, the king stood revenled as merely the most nowerful of the nobles, and it was not so difficult to corry the process to the desired conclusion.

The next serious sten in debilitating the mler wes the strinring off of the military powers throuch the creation of the polemarch. 4 This officer took all military control from the jurisdiction of the king including relisious ond judicial rimts oonnected therewith. The vital blow, was struck, however, in the creation of the Archon

1. Plut. Thes. XXXXY

2. Ibid. $\overline{X X V}$

3. Ibid.

4. Aristotle, The Athenian constitution, III, 2 
who took over the administrative powers of the king. ${ }^{1}$ After the creation of that nw official the king was without nower, for the Archon now did the ruling, the Polemarch went to war, and the King menaged the relicious affairs of the city. Recognizing their impotence the royal dymasty gave un the kingship for the of ice of Archon, 2 and with that step royalty was destroyed. The second sten towerds democracy was the strverle among the nobles for equality. The ring had now become a figurehead in the modern sense of tho expression, and the power of state became concentrated in the Archon because of his capacity for adding new duties to his original administrative responsibilities. But the Archonship was a life job and the exclusive possession of one femily -- the lifedontids. So the Archonship was at some time declared open to the other nobles by means of lirnjting the term of office first to a period of ten years and then in a short time to a one year job wi thout privilege of reelection. ${ }^{4}$ once more nobles had succeeded in destroyine the privileges of one family, and in the future the Archonship would be open to all of the nobility on equal terms.

The Archon with the passege of years had become too powernl, however, and our first historicel glimpse of the thenian government reveals a system of six assistants or Jimior Archons who

1. Arist. Ath. Const. II, 3

2. Ibid.

3. Ibid.

4. Ibid. III, I-2 
took charge of the legal responsibilities of the Major Archons. This measure weakened somewhet the Archon Enonymus (as the Eirst Archon came to be called) but ho was destined to remein the superior of his colleacues.

Meanwile the Council of the Areopagus becan to crow in influence. Then we meet it in history we find it consisting of ex-Archons holding their office for life acting as cuarian of the laws and guarian of the morals of the comrunity. Meeting on the Areopagus and having the relicious function of trying cases of sacrilege the council was destined to be the muling body of the nobility. ${ }^{2}$ Thus as the curtain of history is lifted we find Athens to be a city-state under the mule of an oligarchy of noble families.

The third step towerds democracy took nlece when the common peple gained knowledge of the laws. As the nobles strencthened their hold on the land they opnressed those less fortunate than themselves, and as time passed the nobles continued to increase in worlth while the poorer clesses possed into a condition resembling serfdom. When the cmon people needed heln, their debts became secured on their persons, and failure to meet their obligations entailed forfeiture of their persons or families. 3 As family after family nassed into slavery discontent grew until the commons apparently rose in revolt and demended knowledge of

1. Arist. Ath. Const. II, 4

2. Ibid. III, 6

3. Ibid. IV, 4 
the laws by which they were beine sold into slaverr. The code of Draco was the first important gain for the commons. Their situation was not improved, but they at least knew the law as it had been written by the law-oiver. ${ }^{1}$

The fourth step towards democracy was taken when the nobles and commons began to organize thomselves into factions and to contest for the supremacy. The important feature of Athenian factional disputes is the creation of a third group representing the merchants who were in most cases without citizenship having arrived in the city for business purposes, but without the necessary birth connection for citizensip. With the existence of two disfranchised factions the breakine out of disovtes among the nobility created a situation where the rivel Enpatrids wonld line up one or both of the lower class prouns to min a victory. With the querrel between the descendents of Grion and Acmaeon over the blood taint the factionel strife reached a climay, and the Hill, Shore, ant lain submitted to the arbitration of one man, Solon, who attempted to arrange a compromise for all. 2 With the great constitutional work of Solon the fourth step towards democracr her been completed. For the first time the common peonle had rights, including a jury court and a deliberative body -- the Fcclesia - althoum the concessions were so hedged about with restrictions thet they probably never operated effectively.

1. Plut. Solon, XVII

2. Arist. Ath. Gonst. V, I-3 
The fifth step towards democracy came with the tyrenny of Peisistratus. Taking to hims $1 \mathrm{f}^{\circ}$ the powers of the leing-Archon of old, ${ }^{1}$ Peisistratus and his sons took charge of the administration; and by controllinm the Archonship and areopogus through personal selection of candidates mennced to seriously imnede the political machiner of the nobility. The common folk did not seem to suffer under his rule, but on the contrary benefitted as evidenced by the prosperity making possible the reduction of the tax on produce from ten to five percent. 2 . Solon's laws, however, had been lying dormant so long that the expulsion of Hirpias found them incapable of enctioning as before, 3 and the new Constitution of veisthenes was a distinct gein for democracy since it provided the foundation for seizure of power by the cormon people.

The sixth sten towards democracy came with the Persian Wars which made the common people conscious of their power. Through the exhortations of men such as Themistocles, Aristejdes, and Ephialtes, the neople were made familiar with their strenoth. The attempts of the tyrant Hiprias to regain the city made most Athenians all the more determined to nresorve their city by opposing the principles for which he stood. Themistocles turned the mind of Athens toward the sea ${ }^{4}$ end brought about oreater

1. Diogenes Laertius, Peisistratus to Solon, I, 53

2. Arist. Ath. Const. XII, 4; Thuc. VI, 55

3. Arist. Ath. vonst. XXII, I-3

4. Thuc. I, 94 
participation of the comnon people in the struegle. Aristeides advised the admission of the common people to the aministrative offices, 1 and later alvised the peonle to come down from their forms ant dwell in the oity in order to roin the leadershio of the city. ${ }^{2}$ Ephialtes directed an attack apginst the Areopagus and destroyed the last stronchold of aristocratic anthority. 3 The seventh sten towords denocracr came when the exnansinn of the ompire threw control of affairs into the hands of the naval element. Themistocles, throum his oncouragement nf the corstruction of a lorre navy, laid the fondation of erentual suneriority of the comon people when the emnire develoned, since the many duties connected with the sllies threw controlling power into the hands of the "skippers and boatswains and pilots." 4 The influence of the neval orom toward denocracy was recognized by the aristocrats wh regarded the maritime empire with its expansion of responsibility tomerds the common folle es the "nother of denocracy." 5

Aristeides won the leadership of the allies from Snarta by tactul means and succeeded in oreanizing the Velian Leacue which was pledged to drivo the persian out of the Legenn. The mstom of the allies of peyrne a contribution to the Snartans for the

1. Plut. Aristides, XXII, I

2. Arist. Ath. Const. XXIV, I

3. Plut. Pericles, II, 5-6

4. Plut. Themistocles, XIX, 4

5. Ibid. 
war was continued with Athens and histeides aroostngech city eccording to its ability to nay. ${ }^{1}$ As the duties of Athens spread farther and farther, more and more of her citizens becane involved until the common people vere activel engared in the moritime pursuits of the city. As the citrr became more denendent unon its ompire, in like manner it became dependent uron the will of those who made the ennire possible -- the common people.

The finel step toward democracy was taken when the Ecclesia and Heliaea beran to function in full strength. When the Foclesia began to strip the Council of Five Iundred end the Azeopagus of their restrictive powers, the doom of the aristocracy wos sealed, and the ostracism of cimon ${ }^{2}$ wes morely a symbol of the overwhelming suprenacy of the neople. The nament of the cmmon neonle for jury service mede possible the exercise of the inry privilege by all citizens, while the extending of the final decision in legal matters to the jury assured the common citizens that their rights would be taken care of.

1. Plut. Arist. XXIV, I

2. PIvt. Cimon, XVI, 2 
CON CLUSION 


\section{CONCITSION}

In the course of this work the suthor hes given attention to five forms of the Athenian Constitution. The different neriods considered were 1) the Legendary and Formative (tate; 2) the Reforms of Solon; 3) the Effect of the Deisistratid Trranny; 4! the Cleisthenean Reforms; and 5) the Periclean Constitution. In the course of the discussion ench of the questions propounded in the introduction has been considored at loncth, and thoir interdependent positions have boen pointed out. In sumning up the author would like to recall to the reader the important characteristics of each period in outline form.

In studving the Atrenian Constitution we saw among other things:

1. That thero was already a constitution when solon came to power

a) that it consisted of o class system

b) that the Archonship was well established

c) that the reonamas controlled the administration of affeirs and was the center of rower in the city

d) that the Ecclesia was in existence though annarently not very strong 

e) that jury courts were in existence thourh probably for exclusive use of the nobility
f) that the Council of Four Hundred existed, and excluded the Thetes
g) that the strategi were elected by the citizens

2. That Solon's reforms were based upon the then existing constitution
a) that the tribal system was undisturbed
b) thet the upner classes continued to mile
c) that his reforms were a compromise oiving the people no more power then was necessary
d) that he centered the power of his system in the Aroopagus
e) that the lower classes were armitted to the foclesia
f) that the Council of Four Hundred was strengthened and checked the Ecolesia
g) that the Helieea was the center of Solon's democratic reforms

3. Thot the Peisistratids did not seriously interfere with the Solonian Constitution
a) that thoy held administrative powers according to the pre-Solonian Archonship
b) that as administrators they could assess and collect taxes
c) that as administrators they covld dominate the Council
d) that they had administrative control of the courts 

e) that they were heads of the people, thus dominating the Ecclesia
f) that they did not hold legislative or judicial powers
c) that the tyrany negated the laws throum disuse, not by destroyine them

4. That Cleisthenes's Constitution was based upon the Solonian model
a) thet the tribal reorcanization was the principal change
b) thet the Council of Five Hundred was a direct result of the tribal change
c) that the Archonshin wes not seriously affected
d) that the Areopagus retajned sovereign power in the state
e) that the Ecclesia held theoretioal power although it did not exercise it
f) that ostracism was a weapon of control

5. That the Periclean Constitution was entirely damocratic

a) that the Archons were ontirely subserviont to the will of the neople

b) that the Areopagus retained only its oncient powers over public morals

c) that the Council of Five Hundred was subject to the will of the Ecclesia

d) that all covernmental power centered in the Ecolesia and its will 
e) that the Helinea was the guarantee of the peoples' power

f) that the Generalship, though the agency of leadership, was subject to the Ecclesia

Having given consideration to the above outlines, I submit that the seven main points of the thesis have been proved. From the study as conducted from the legondary period to the days of Pericles it has been evitent that

1. There was a constitution functioning when solon came to power.

2. Solon's Constitution was a constitution of the nobility, and all democratic powers were effectually checked.

3. Peisistratus did not destroy the Constitution of Solon but operated under it using the laws for his position as administrator with the old powers of the life-Archon.

4. Cleisthenes's reforms did not have the domocratic effect that is commonly supposed, but took place gradually.

5. Cleisthenes definitely increased the power of the Ecclesia or popular Assembly.

6. The Ecclesia was the instmment by which complete democracy was achieved, and the Feliaea were used as a means of backing up the decisions of the Ecclesia.

7. The development of democracr was due to the rise of Athens commercially, and a partial result of her imperialisin. 
B. C. $650-630$ The Six Thesmothetae

632 Cylon's Conspiracy

629 Megarian War

621 Draco's Code

620 Banishment of the Alcmaeonids

599 Trial of the Mlmaeonids

594 Solon's Code

588 No Archon Appointed because of Party Strife

583 Tyranny of Danasias

581 The Ten Archons Instituted

570 Peisistratus (Polemarch) seainst Megara (Salamis, Nisaea)

565 Conquest of Salamis

560 Peisistratus Tyrent at Athens

559 Death of Solon

559-556 Acauisition of the Thracian Chersonese by Piltiades

556 First Exile of Peisistratus

550 Second Tyranny of Peisistratus

549 Second Exile of Peisistratus

539 Third Tyranny of Peisistratus

535 Recapture of Si geum

527 Death of Peisistratus; accessinn of Hippias to the Tyranny

514 Assassination of Hipparchus

510 Expulsion of the Peisistratids; Athens Enters the Peloponnesian League

508 Constitution of Cleisthenes; Isagoras Archon

507 Cleisthenes Institutes his Reforms; Isagoras Defeated

506 Defeat of Cheloidians and Boeotions by Athens

503 Cleisthenian Constitution Goes into Effect

502 Oath of Induction for the Council of Five Hundred

501 Institution of the Ten Cenerals

499 The Ionian Revolt

498 Burning of Sardis

496 Darius's Soythien Expedition

494 Suppression of the Ionic Revolt; Piltiades seizes Lomnos

493 Themistocles Archon; Persians Concuer Thrace

492 Miltiades flees from Chersonese to Athens

491 Persia Demands Earth and Water

490 Battle of Marathon

489 Aristeides Archon

487 Archons Chosen by Lot out of Council of 500; Hipparchus Ostracised 486 Accession of Xerxes; Fgypt Revolts from Persia; Megacles Ostracised 485 Unknow Friend of the Tyrants Ostracised

484 Egyptian Revolt Suppressed; Xanthippus Ostracised 
482 Themistocles Develons Navy; Aristeides Ostrecised

480 Thermopylae and Salamis; Ostracised Cenerals Recalled; Areopagus Begins Loadership of Corstitution

479 Plataea and Pycale; Aristeides General with Sole Powers

478 Delian Leame Instituted; Aristeides Assesses the Tribute; Capture of Sestos

477 Aristeides Advises Ionians to Come down from Farms and Live in the City to Keen Leadership of Public Affairs

476 Themistocles Rebuilds the Athenian Walls; Cimon Captures Eion

174 Cimon Conquers Scyrus

472 Cimon Reduced Carystus; Themistocles Ostracised

470 Naxos Secedes from the Delian Iengue

468 Suppression of Naxos by Cimon

467 Cimon's Victory at Eurymedon; Death of Aristeides

466 Cimon Victorious at the Hellesnont

455 Revolt of Thesos

463 Cimon Conquers Thesos; Pericles Challenges the Andits of Cimon;

The Areopagus Relinquishes Leadershin of the Constitution

462 Reforms of Ephialtes and Pericles; Cimon Rebuffed br Snarta

461 Cimon Ostracised; Pericles Supreme

457 Archonship Opened to the Zenoitae 
Aristotle, The Athenian Constitution, with an English trenslation by $\mathrm{H}$. Kackham, Harverd Tniversity Press, Cambridge, 1935

The principal source for the thesis. In general the constitution is accurate and decendable. Aristotle is mostly interested in the mechanics of government in Athens and sketches the high points in constitutional development from the legendar neriod to the government of his day. Reference to later sections is frequently necessary in order to comprehend earlier governmental bodies.

Aristotle, The Politics, with an English translation by I. Rackham, G. P. Putnam's Sons, New York, 1932

A general work on govermment. Postly theoretical in nature the value of the Politics lies in its illustrations which frequently fortify or elaborate upon a noint introduced briefly in the constitution. Dhe to its universal charecter care must be exercised in making use of its materials subordinating them to information gained from the work on the constitution.

Plutarch, Parallel Lives, with on English translation by Bernadotte perrin, Il volumes, Williem Feinemenn, Lonton, 1914

Theseus, Themistooles, Aristides, Solon, gimon, and Pericles are the worles used. Were of rreat importance and second only to the Constitution of Aristotle. As a moralist Plutarch directed his attention toward the actions of his characters with reference to their moral effect on the state and themselves. It is through this approach that much wes coined relative to the motives for eroh statesman's actions.

Plutarch, Moralia, Finglish translation by $M$. Mowler, 14 volumes, Harvard University Press, Cembridge, 1936

of little value excent for confirming informetion found in other works. Occasionally references clarify the inner workings of the govemmental agencies. N11 infornation in these works must be gleaned by careful reading. Tsually the information desired is treated as an unimportent or isolated reference to a topic unrelated to the purpose of the thesis. 
Herodotus, History, with an English translation by A. D. Codley, 4 volumes, Williom Heinemenn, London, 1920

A work of nrimary importance where nolltical events are concerned. The relations of Athens with noimhorinm city-states are of major interst to Jerodotus. Varions intrimes between fections are of special interest. All events bearing on the military develoment

of the Persian Wars are treated. Because of his neamess in noint of time to his subject, Herodotus is usually most dependable in cases of conflict, and was accepted by the author when in doubt.

Thucydides, The Pelononnesian War, translated by Crawley, Tho Modern Library, New York, 1934

The most dependeble of all sources, but limited in its scope. For the purposes of the thesis information was restricted to a few early chapters and a digression toward the end of the work. The Periods of peisistratus and Pericles were the most valuable extracts from the work, but due to the cere exercised by Thucydides in the selection and use of his materials practically all of his statements could be accented at foce value.

Diogenes Laertius, Lives of Eninent Philosophers, with an Enclish trenslation by T. D. Miles, 2 Tolumes, C. P. Putnens Sons, New York, 1925

Solon, and Peisistratus's letter to solon are the rories used. In general solon only reveats Pluterch's fuller version, and due to the cereless use of his sourcos Diogenes Laertius must always be accepted with a guestion marl. The letter, however, is valuable since it indicates Peisistratus's concention of his position in Athens after the establishment of the tyranny.

Cornelius lepos, Iives of the reat cenerals, with an Nolish trenslation by J. C. Rolfe, (bound with Florus Enitome of Roman History), Tilliam Heinemenn, Iimited, London, 1929

Miltiades, Themistocles, and Aristides were the works used. of the three Miltiades is the most important although Nepos confuses the early Miltiedes with his ereater nerhew of the seme name. The line of demercation is eesily dram, however, and the work is of value as the only exclusive treatment of that importent man. The other works are of little interest except for isoleted details. All three accounts are sketchy in nature and brief in treatment. 
Pausanias, Description of Creece, 6 volumes, with an Fnclish translation by W. H. S. Jones, William Heinemann, London, 1918

The author is mostly interested in antiguities, and the little historical information is merely incidentel backoround for his word trovels. All date oleaned from the first section on Attica (tho only section used) is of an isoleted character and merely confirms moterjals arrearing in other worles.

Xenophon, Memorabilia, and Oeconomicus, with an Fnlish translation by E. C. Marchant, William Heinemann, London, 1923

Similar in character to Fluterch's "emorabilia. Of little value to this work except for a few references on the male-un of the Ecclesio.

Isocrates, with an Enmlish translation by feorme lorlin, 3 volumes, C. P. Putnam's Sons, New York, 1929

The Areopariticus is one of the tro works used. Its chief value lies in the conception which the antror had of the ireopagus in its period of power and honor as leacer of the state. Some idea of the dipnity and influence of that bory is indiceted in the work. The second work used, Panathenaicus, contains isolated referencos to Themistocles.

Cicero, De Natura Deorum, Enclish translation by L. Recksham, c. P. Putnam's Sons, New York, 1953

Has no connection with the study of the Athenien Constitution. Excent for one reference to the understood preeminent position of the Council of the Areonams, the worl has no use for the purnose at rend.

George Grote, A History of Greece, 4 volunes, Wm. L. Allison, New York

The earliest and still one of the ost important works on Greece from the earliest ti es to Alexender the Great. Based upon a careful s tudy of the classicel sources, the history is quite detailed and valuable for study involving interpretations of the classics. For the Athenian Constitution certain edjustmonts must be made in view of the fact that the anthor produced his worl before the discovery of Aristotle's Athonian Constitution. Otherwise the work is still of great practical value. 
J. B. Bury, A Eistory of Greece, The Nodern Library, New York, 1937

Probably the best known work on ancient Freece embracing the usual period. Not quite so detailed as crote, the Bury history is superior in that it embodies many of the recent findines in archaeolocy as well as the all-important work of Aristotle on the Constitution of Athens. A literary as well as scholarly work, the history was one of the principel reference works utilized in preparation of the thesis. It wos especially helpful in nlacing datos.

Ceorge W. Botsford, Hellenic History, The Macllillan Comnany, New York, 1925

A scholarly worle with emphasis on the onltural aspects of anoient Greece. Although a brief treatment the Botsford history is extrenely useful for reference due to complete system of footnotes which direct the reader to the elassical sources. Mnch material was produced for the thesis throuch references to these footings which might othervise have been missed.

Alfred Zimmern, The Greek Commonwealth, fourth edition, revised, The Clarendon Press, Oxford, 1924

An interesting work on Greek institutions and civilization. It is devoted to a study of Athens, and is a mesterly attempt to reconstruct ancient thought and urnose. Well documented and lately revised the work of $Z$ imnern is up to date and profitable within its scope. The footnotes served to aid in preperation of the thesis ilthough not to the extent of Botsford.

W. Warde Fowler, The Citv-St,ate of the Creeks and Romans, Macmillan and Co., Limjted, London, 1931

A hendy little work on the origins of democratic covernment and the conflict between the nobility and the lower classes. Al though a general work end somewhat old (the text dates back to 1895) the general lines of thou ht are still accentable. As is true with Grote, several details are out of line with latest discoveries mostly through leck of acquaintanoo with Aristotle's Atrenion Constitution. The period of this thesis is exactly covered by the work. 